\title{
Temporal variation in end-member chemistry and its influence on runoff mixing patterns in a forested, Piedmont catchment
}

\author{
Shreeram Inamdar, ${ }^{1}$ Gurbir Dhillon, ${ }^{1}$ Shatrughan Singh, ${ }^{1}$ Sudarshan Dutta, ${ }^{1}$ Delphis Levia, ${ }^{1}$ \\ Durelle Scott, ${ }^{2}$ Myron Mitchell, ${ }^{3}$ John Van Stan, ${ }^{4}$ and Patrick McHale ${ }^{3}$ \\ Received 16 April 2012; revised 19 February 2013; accepted 20 February 2013; published 11 April 2013.
}

[1] Runoff mixing patterns for base flow and 42 storm events were investigated for a 3 year period (2008-2010) in a 12 ha forested catchment in the mid-Atlantic, Piedmont region of the USA. Eleven distinct runoff sources were sampled independently and included:

precipitation, throughfall, stemflow, litter leachate, wetland soil water, tension soil water, shallow groundwater, groundwater seeps, hyporheic water, riparian groundwater, and deep groundwater. A rigorous end-member mixing analysis (EMMA) was implemented and all base flow, storm-flow, and end-member chemistries were evaluated in a two-dimensional mixing space. End-members enclosed stream water chemistry and displayed a systematic continuum in EMMA space. Base-flow chemistry of stream waters was similar to groundwater seeps. Storm-event runoff was attributed to contributions from surficial sources (precipitation, throughfall, stemflow, and litter leachate) on the rising limb of the discharge hydrograph that was followed by soil and shallow groundwater sources on the recession limb of the hydrograph. The shapes of the storm-event hysteresis loops (wide versus tight, linear patterns) varied with hydrologic conditions from wet, hydrologically well-connected conditions to a dry, disconnected state. Detailed temporal data on endmember chemistry allowed us to explain the changes in stream water hysteresis patterns and runoff mixing space to shifts in end-member chemistry that occurred as the catchment became hydrologically disconnected. These results highlight the need to recognize the temporal variation in end-member chemistry as a function of catchment wetness and the need to collect high-frequency data on both - stream water as well as potential runoff endmembers to better characterize catchment flow paths and mixing responses.

Citation: Inamdar, S., G. Dhillon, S. Singh, S. Dutta, D. Levia, D. Scott, M. Mitchell, J. Van Stan, and P. McHale (2013), Temporal variation in end-member chemistry and its influence on runoff mixing patterns in a forested, Piedmont catchment, Water Resour. Res., 49, 1828-1844, doi:10.1002/wrcr.20158.

\section{Introduction}

[2] The use of tracers and mixing models has provided tremendous insights into runoff sources and watershed flow paths [Buttle, 2005; Inamdar, 2011; James and Roulet, 2006; Jung et al., 2009; Sebestyen et al., 2008; Shanley et al., 2002, 2011; Soulsby et al., 2003]. These models assume that catchment runoff is a mixture of unique runoff sources whose contributions can be determined using naturally occurring solutes or tracers [Hooper, 2003]. Key assumptions for mixing models include: (a) the tracers

\footnotetext{
${ }^{1}$ Plant and Soil Sciences, University of Delaware, Newark, Delaware, USA.

${ }^{2}$ Biological Systems Engineering, Virginia Tech, Blacksburg, Virginia, USA.

${ }^{3}$ College of Environmental Science and Forestry, State University of New York, Syracuse, New York, USA.

${ }^{4}$ Department of Geology \& Geography, Statesboro, Georgia, USA.

Corresponding author: S. Inamdar, University of Delaware, 264 Townsend Hall, 531 S College Ave., Newark, DE 19716, USA. (Inamdar@ udel.edu)
}

(C)2013 American Geophysical Union. All Rights Reserved. 0043-1397/13/10.1002/wrcr.20158 behave conservatively, i.e., the tracer concentrations do not change due to biogeochemical processes over the time scale considered by the mixing model; (b) the mixing process is linear; (c) the chemical composition of end-members (tracer concentrations) does not change over the time scale considered by the mixing model (time invariance); and (d) the chemical composition of end-members (tracer concentrations) does not change with space (space invariance). Early applications of mixing models solved mass balance equations for a minimum number of tracers required to identify the runoff components [Bazemore et al., 1994; Dewalle et al., 1988; Sklash et al., 1976]. In the 1990s however, Christopherson and Hooper [1992] and Hooper et al. [1990] introduced multivariate statistical analyses that used a suite of tracers (e.g., cations, anions, and silica) for mixing models. This methodology was referred to as end-member mixing analysis (EMMA) since the key geographic sources of runoff were labeled as "end-members". Since the introduction of EMMA, the interest in using geochemical mixing models as an investigative tool to identify runoff sources has increased dramatically [see Inamdar, 2011 for a review]. While some of these studies have confirmed our conceptual models of watershed behavior, others have raised new questions and even challenged the existing paradigms of 
watershed response [e.g., Hooper, 2001; Robson et al., 1992]. Mixing models have especially been valuable for understanding watershed behavior when they have been used in conjunction with independently measured hydrometric data [Bonell, 1998; Buttle, 2005].

[3] EMMA models have been instrumental in identifying runoff sources during and between storm events [Hangen et al., 2001; Inamdar and Mitchell, 2007; McGlynn and McDonnell, 2003; McHale et al., 2002; Morel et al., 2009; Verseveld et al., 2008; Wenninger et al., 2004]. The relative proportions of contributions from runoff sources have been found to vary with catchment moisture and/or hydrologic conditions [Bernal et al., 2006; Morel et al., 2009]. Key sources that have been found to contribute to catchment runoff include-precipitation, throughfall, litter leachate, soil water, riparian groundwaters, and hillslope waters. Burns et al. [2001] identified the riparian zone, hillslope, and a rock outcrop as the three main sources of runoff, with riparian groundwater contributions being highest during early parts of the event and the recession period and runoff from the rock outcrop composing a majority of the discharge at peak flow. McGlynn and McDonnell [2003] reported elevated contributions from the riparian zone for small events and for the early portion of large events whereas hillslope contributions were at their highest during peak discharge for large storms. For forested catchments in Western New York, USA, Inamdar and Mitchell [2007] presented a three-stage runoff model for storms that included contributions, in order, from groundwater seeps, throughfall and riparian waters. Using mixing models for an agricultural catchment in France, Morel et al. [2009] found that runoff was composed of precipitation on the ascending limb on the hydrograph, wetland soil water contributions occurred after peak discharge and on the recession limb and shallow and deep groundwaters composed base-flow and storm recession. Ali et al. [2010], James and Roulet [2006], Inamdar and Mitchell [2007], and Morel et al. [2009] have shown that the runoff sources and their relative contributions vary considerably with event size and antecedent moisture conditions. For example, Ali et al. [2010] reported that contributions from throughfall and organic soil water were elevated during wet antecedent conditions that enhanced hydrologic connectivity with surficial sources of runoff, but not so during low discharges and dry antecedent moisture conditions. These observations underscore the need to assess mixing diagrams under a range of hydrologic conditions.

[4] While EMMA studies have been successful in characterizing flow paths and have helped develop new conceptual models of runoff generation, greater attention needs to be paid to the underlying assumptions and conditions under which they may be violated. Temporal variation in chemistry of watershed sources or end-members is a recognized problem [Ali et al., 2010; Barthold et al., 2011; Durand and Torres, 1996; Rice and Hornberger, 1998] and is one of the key assumptions of EMMA that may often be violated. Such changes in end-member chemistry could occur because of hydrologic as well as biogeochemical processes in the catchment. One of the ways to address this problem or relax this assumption has been through the continuous monitoring of end-member chemistry and the selection of end-member solute concentrations in the immediate temporal vicinity of storm events being evaluated for EMMA
[Burns et al., 2001]. However, previous watershed studies have typically monitored only a few watershed sources for a limited time. Understanding how end-member chemistry may evolve with time and its implications for runoff mixing patterns is critically needed. It should also be noted that while many studies have identified discrete end-members and assigned specific runoff proportions to them, the selection of these end-members may not be a completely objective process and may be subject to uncertainty. R. P. Hooper and B. Rudolph (Interpreting hysteresis in concentration-discharge models using mixing approach, unpublished data, 2009, hereinafter referred to as Hooper and Rudolph, unpublished data, 2009) have recommended that focusing on precise end-member contributions may not be important or even reliable, but investigating the arrangement and relative positioning of all potential end-members with respect to stream runoff in EMMA space may be more helpful in furthering our understanding of catchment runoff response.

[5] Our interest here was to address this important gap in our knowledge and investigate how hydrologic and seasonal changes in catchments alter end-member chemistry and how this in turn influences storm runoff mixing patterns. This study was conducted in a 12 ha forested catchment located in the mid-Atlantic, Piedmont (Maryland) region of the USA. Watershed sources and stream runoff was sampled continuously for base-flow and storm events over a period of 3 years (2008-2010) representing a wide range of hydrologic and storm-event conditions. Eleven distinct watershed sources (potential end members) that were sampled independently included: precipitation, throughfall, stemflow, litter leachate, wetland soil water, tension soil water, shallow groundwater, groundwater seeps, hyporheic water, riparian groundwater, and deep groundwater. Chemistry for all of these end-members along with stream water was evaluated in EMMA space for storm events occurring over different seasons and hydrologic conditions. Following Hooper and Rudolph's (unpublished data, 2009) recommendation, we assessed the influence of all end-members on stream water chemistry and did not constrain ourselves to selected end-members and their runoff proportions. This study builds on our previous EMMA work for this catchment [Inamdar et al., 2011] that was limited to characterizing the hydrologic flow paths for dissolved organic matter for a selected set of storm events. Here we expand and modify the analyses with a slight change in tracers and inclusion of all 42 storm events from 2008 to 2010 to conceptualize a broadly applicable hydrologic mixing model. We hypothesize that temporal changes in end-member chemistry and catchment hydrologic connectivity associated with diverse hydrologic (moisture) and seasonal conditions will determine the shapes and hysteresis patterns for storm-runoff mixing loops. Specific questions that we address are: (1) What are the sources and flow paths for stream runoff? (2) How does temporal changes in end-member chemistry for diverse catchment hydrologic conditions shape runoff mixing patterns?

\section{Site Description and Methods}

\subsection{Site Description}

[6] The study catchment (12 ha) is located within the Fair Hill Natural Resources Management Area (NRMA) $\left(39^{\circ} 42^{\prime} \mathrm{N}, 75^{\circ} 50^{\prime} \mathrm{W}\right)$ in Cecil County, Maryland, USA 
(Figure 1, inset). This catchment has been intensively instrumented and studied as a part of an ongoing study [Inamdar et al., 2011, 2012]. The catchment drains into the Big Elk creek which lies within the Piedmont physiographic region and eventually drains into the Chesapeake Bay. Cecil County has a humid, continental climate with well-defined seasons. The 30 year climate norm (19812010) for northeastern Maryland reveals a mean annual precipitation of $1205 \mathrm{~mm}$. Snowfall is approximately 450 $\mathrm{mm}$ and is concentrated in a few events with a quick melt of the snowpack. The highest mean monthly air temperature is $25.7^{\circ} \mathrm{C}$, occurring in July. The lowest mean monthly air temperature of $-0.1^{\circ} \mathrm{C}$ occurs in January [Maryland State Climatologist Office Data Page, 2012]. Late summer (August-September) is the driest period of the year with respect to soil moisture and stream runoff while late spring (April-May) is the wettest.

[7] The study area is underlain by the Mt. Cuba Wissahickon formation and includes pelitic gneiss and pelitic schist with subordinate amphibolite and pegmatite [Blackmer, 2005]. The soils in the study area belong to the Glenelg series, which consists of deep, well drained, nearly level to moderately steep soils. On the hillslopes, soils are coarse loamy, mixed, mesic Lithic Dystrudepts while in the valley bottoms seasonal water saturation leads to the formation of Oxyaquic Dystrudepts. The backslope soil profile

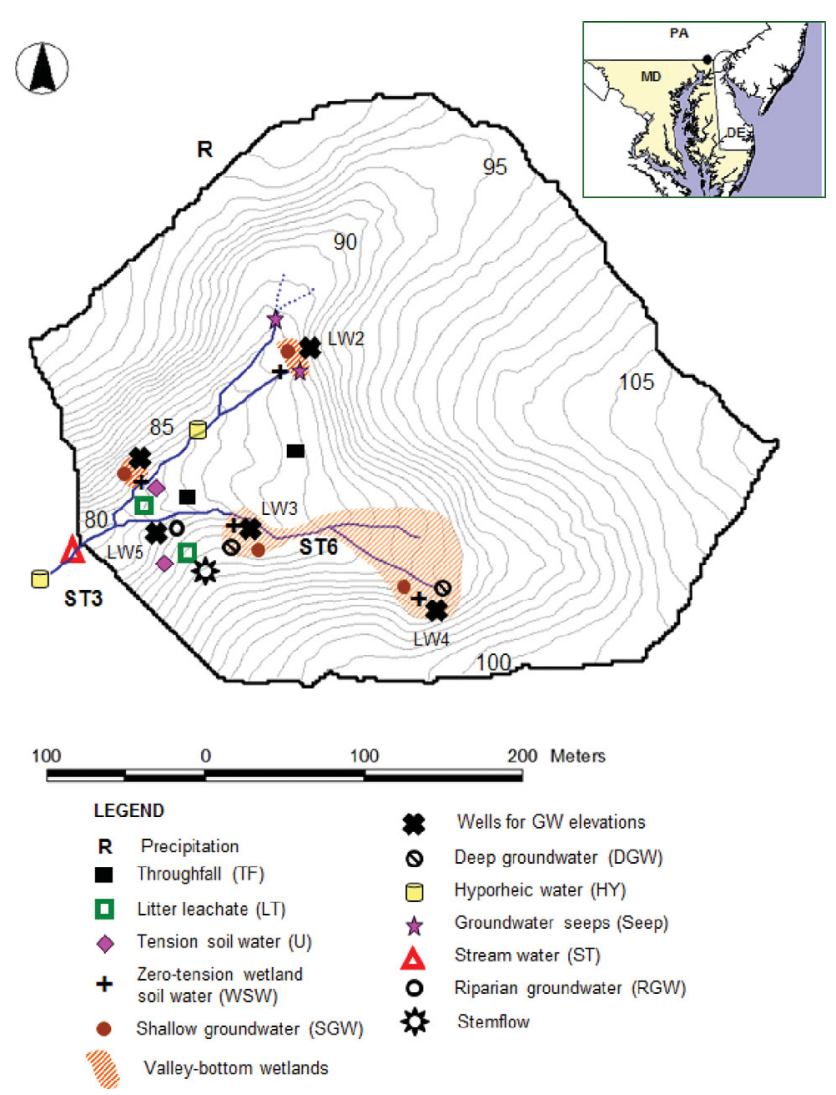

Figure 1. Location of the 12 ha study catchment in the state of Maryland, USA (inset) and sampling locations for watershed sources (runoff end-members). Base-flow and storm-event runoff was collected for stream water at the catchment outlet at ST3. has an $8 \mathrm{~cm}$ thick organic A horizon which shows a granular to small subangular structure. The boundary to the first B horizon is diffusive. At $22-45 \mathrm{~cm}$ below the surface the higher clay content indicates translocation of clay minerals into lower portions of the soil profile. The boundary to the $\mathrm{C}$ horizon at $68 \mathrm{~cm}$ depth is gradual. Elevation in the 12 ha watershed ranges from 77 to $108 \mathrm{~m}$ above mean sea level. Slope gradients range from $0.16^{\circ}$ to $24^{\circ}$. Vegetation in the study catchment consists of deciduous forest with pasture along the catchment periphery. Dominant tree species are Fagus grandifolia (American beech), Liriodendron tulipifera (yellow poplar), and Acer rubrum (red maple) [Levia et al., 2010]. Additional details about the catchment are available at: http://udel.edu/ inamdar/fairhill.htm.

\subsection{Hydrologic Monitoring}

[8] Precipitation and air temperature data were available at 5 min frequency from a weather station located in the Fairhill NRMA, about $1000 \mathrm{~m}$ from the outlet of the 12 ha catchment. Streamflow discharge was monitored at the outlet of the 12 ha catchment (ST3 in Figure 1) using a 6 inch Parshall flume and water flow depths were recorded every 20 min using a Global Water (Inc.) logger and pressure transducer. Depth to groundwater (from the soil surface) was recorded at five locations (Figure 1) in the 12 ha catchment at 30 min intervals using Global Water loggers (Inc.). Groundwater logging wells consisted of PVC pipes (5 $\mathrm{cm}$ diameter) $\sim 2 \mathrm{~m}$ below the ground surface that were continuously slotted from a depth of $0.3 \mathrm{~m}$ below the soil surface. All data were collected over the period of 2008-2010.

\subsection{Water Sampling and Chemistry}

[9] Stream water samples were collected during storm events as well as base-flow periods over the three period of 2008-2010. Storm-event sampling for stream water at the outlet of the 12 ha catchment was performed using an automated ISCO sampler which was triggered to sample when the rainfall amount exceeded $2.54 \mathrm{~mm}$ in a $1 \mathrm{~h}$ period. The ISCO samples were collected in the "nonuniform" program model with a sampling frequency that ranged from as low as $15 \mathrm{~min}$ on the hydrograph rising limb to $3 \mathrm{~h}$ on the recession limb. In addition to stream water, precipitation (one location), throughfall (two locations), bulk stemflow (from both $F$. grandifolia and L. tulipifera; one experimental plot within 12 ha catchment), and litter leachate (forest floor; two locations) samples (Figure 1 and Table 1) were also collected within $24 \mathrm{~h}$ following storm events. Precipitation and throughfall samplers consisted of $1 \mathrm{~L}$ amber glass bottles that collected water through a plastic funnel. Litter leachate samplers consisted of $1 \mathrm{~L}$ amber glass bottles connected to (via plastic tubing) plastic trays $\left(\sim 1 \mathrm{~m}^{2}\right)$ that contained the $\mathrm{O}$ horizon layer.

[10] Manual grab samples were collected during base flow for stream water at ST3 as well as various watershed sources (every 2-3 weeks during 2008-2009 and every 4 weeks 2010 onwards). Other watershed sources includedzero-tension wetland soil water (WSW); tension soil water (U); wetland shallow and deep groundwater (SGW and DGW, respectively), riparian groundwater (RGW), groundwater seeps (Seep) and hyporheic water (HY) (Figure 1). Wetland soil water was sampled at four sites (Figure 1) in 
Table 1. Catchment Runoff Sources (Potential End-Members) and Their Sampling Information Including — Sampled Period, Sampling Frequency and the Number of Samples Collected for the 3 Year Study Period (2008-2010)

\begin{tabular}{|c|c|c|c|c|c|}
\hline Runoff Source/End-Member & $\begin{array}{l}\text { Abbreviation/ } \\
\text { Symbol }\end{array}$ & $\begin{array}{l}\text { Period of } \\
\text { Sampling }^{\mathrm{a}}\end{array}$ & $\begin{array}{l}\text { Occurrence } \\
\text { of Sampling }\end{array}$ & $\begin{array}{l}\text { No. of Sampling } \\
\text { Locations }\end{array}$ & $\begin{array}{c}\text { Total No. of } \\
\text { Samples Collected }\end{array}$ \\
\hline Precipitation & $\mathrm{R}$ & Apr. 2008-2010 & Storm & 1 & 40 \\
\hline Throughfall & $\mathrm{TF}$ & 2008-2010 & Storm & 2 & 95 \\
\hline Stemflow & Stem & Nov. 2007-2010 & Storm & 1 nest with multiple trees & 73 \\
\hline Litter leachate & LT & 2008-2010 & Storm & 2 & 93 \\
\hline Wetland soil water (zero tension) & WSW & 2008-2010 & Base flow/grab & 3 & 108 \\
\hline Tension soil water & $\mathrm{U}$ & Jul. 2008-2010 & Base flow/grab & & 105 \\
\hline Shallow ground water & SGW & 2008-2010 & Base flow/grab & 3 & 110 \\
\hline Riparian ground water & RGW & $2008-2010$ & Base flow/grab & 1 & 38 \\
\hline Deep ground water & DGW & 2008-2010 & Base flow/grab & 2 & 82 \\
\hline Hyporheic water & HY & Apr. 2008-2010 & Base flow/grab & 2 & 78 \\
\hline Groundwater seeps & Seep & 2008-2010 & Base flow/grab & 2 & 92 \\
\hline
\end{tabular}

${ }^{\text {a }}$ Selected storms events were sampled during the period indicated.

the valley-bottom wetlands. The soil water was sampled using zero-tension lysimeters which consisted of screened 5 $\mathrm{cm}$ diameter PVC pipes that were inserted at a 45 degree angle to a depth of $30 \mathrm{~cm}$ in valley-bottom wetland soils. These samplers collected soil water via gravity flow and contained soil water year-round. Tension soil water samples were collected using two nests of two suction cup tension lysimeters (Soilmoisture Equipment Corp.) each at 10 and $30 \mathrm{~cm}$ depths. A suction of 70 centibars was applied to these lysimeters prior to the day of sampling. Shallow groundwater samples were collected from four wells located in the valleybottom wetlands (Figure 1) and was constructed of $5 \mathrm{~cm}$ PVC tubing, augured to $2 \mathrm{~m}$ and screened for the full length from $30 \mathrm{~cm}$ below the soil surface. Two deep groundwater wells were collocated with shallow groundwater wells in the wetlands and were screened only for the lowermost $50 \mathrm{~cm}$ so as to collect only the deeper portion of groundwater (1.5-2 $\mathrm{m}$ below the soil surface). The riparian groundwater well was identical to shallow groundwater except that it was located in a riparian location which was not a wetland (Figure 1). Hyporheic samples were collected at two stream locations (Figure 1) and consisted of slotted PVC pipes (5 cm diameter) inserted at a $45^{\circ}$ angle to a depth of $30 \mathrm{~cm}$ in the stream bed. All samples from soil and groundwater locations were recovered using a hand-operated suction pump. Seep samples were collected manually at two headwater seep locations. The sampling duration, frequency and total number of samples collected for each watershed source is listed in Table 1.

\subsection{Sample Processing and Chemical Analyses}

[11] All samples were collected in HDPE bottles, filtered through a $0.45 \mu \mathrm{m}$ filter paper (Millipore, Inc.) within $24 \mathrm{~h}$ of collection and stored at $4^{\circ} \mathrm{C}$. The Biogeochemistry Laboratory at SUNY-ESF, NY, which is a participant in the USGS [2008] QA/QC program, performed the following analyses: major cations $\left(\mathrm{Ca}^{2+}, \mathrm{Mg}^{2+}, \mathrm{Na}^{+}, \mathrm{K}^{+}\right)$, silica $(\mathrm{Si})$ and total aluminum (Al) using a Perkin-Elmer ICP-AEC Div 3300 instrument; and DOC using the Tekmar-Dohrmann Phoenix 8000 TOC analyzer.

\subsection{End-Member Mixing Analysis (EMMA)}

[12] EMMA was performed following the procedures of Christopherson and Hooper [1992] and Hooper [2003]. For a detailed description and the specific steps, the readers are referred to Hooper [2003] and Inamdar [2011]. The mass balance equations that are solved for EMMA and other geochemical mixing models are:

$$
\begin{gathered}
Q_{t}=\sum_{i=1}^{n} Q_{i}, \\
Q_{t} C_{t}^{j}=\sum_{i=1}^{n} Q_{i} C_{i}^{j} \quad \text { where } j=1, \ldots,(n-1),
\end{gathered}
$$

where $Q_{t}$ is the catchment outflow or streamflow, $Q_{i}$ is the contribution from the end-member or runoff component $i$, and $C_{i}^{j}$ is the concentration of tracer $\mathrm{j}$ for end-member $i$. Typically, the solution of these equations for $n$ end-members requires a minimum of $n-1$ tracers.

[13] Tracers that behave conservatively are vital for a successful application of EMMA and Hooper [2003] recommended that assumptions of linearity of mixing and conservative behavior of tracers can be evaluated using bivariate scatter plots and residuals derived from the selected model. Hence, bivariate plots were developed for all solutes and those that displayed the best linear fits were selected. Tracers that could help differentiate between surficial and groundwater flow paths were especially targeted. Stream water concentrations of selected tracers for all storm events from 2008 to 2010 were collated. These concentrations were then normalized/standardized using the associated mean and standard deviation for each tracer and a correlation matrix was developed [Hooper, 2003]. Principal component analysis (PCA) was performed on the correlation matrix to determine the Eigen vectors and values [Hooper, 2003]. The first two principal components were used to generate a two-dimensional mixing space (or $\mathrm{U}$ space) defined by stream water chemistry. Tracer concentrations for all sampled watershed sources (precipitation, throughfall, litter leachate, soil water, groundwater, etc.) were then normalized to the storm-event stream water concentrations and projected into the two-dimensional mixing space [Hooper, 2003].

[14] The same procedure was followed for base-flow data. This allowed us to compare the stream chemistry for storm events against base flow and the watershed sources in EMMA mixing space. While a three end-member model 
explained a large portion $(\sim 90 \%)$ of the variability in stream chemistry, we proposed that the stream chemistry was likely a mixture of a continuum of watershed sources and thus did not constrain ourselves to only three endmembers and did not determine individual fraction or percent contributions for any selected end-members. Rather, we believed that studying the storm event and base-flow chemistry in the mixing space (U space) along with all sampled watershed sources provided a more comprehensive assessment of stream water chemistry versus constraining the analyses with selected end-members.

\subsection{Characterization of Hydrologic Conditions in the Catchment}

[15] Hydrologic conditions in the catchment for storm events were characterized using a combination of precipitation, stream discharge and groundwater depth data. Precipitation data for events included - total amount ( $\mathrm{mm}), 5 \mathrm{~min}$ maximum intensity $(\mathrm{mm})$, and sum of precipitation 7 days prior to the event (API7; mm). Stream discharge data used were total streamflow discharge $(\mathrm{mm})$, peak flow rate $(\mathrm{mm} /$ $\mathrm{h}$ ), runoff ratio, and average discharge for $24 \mathrm{~h}$ prior to the storm event (AQ24hr; $\mathrm{mm} / \mathrm{h}$ ). In addition, average groundwater depths (depth from soil surface, $m$ ) for three wells LW2, LW4, and LW5 were also used to characterize the antecedent moisture conditions in the catchment prior to the storm events. The groundwater depth metrics included AQ24hr and API7; average of groundwater depths $24 \mathrm{~h}$ and 7 days prior to the event, respectively.

\section{Results}

\subsection{Selected Tracers and Their Concentrations in Stream Water and Watershed Sources}

[16] Evaluation of bivariate plots revealed that sodium $(\mathrm{Na})$, calcium $(\mathrm{Ca})$, total aluminum $(\mathrm{Al})$, silica $(\mathrm{Si})$, and dissolved organic carbon (DOC) provided the best linear fits, demonstrating their suitability for EMMA (Figure 2). Calcium was clearly the weakest of the selected tracers. However, removal of $\mathrm{Ca}$ from the selected suite of tracers did not change the final EMMA results, thus we persisted with the choice of the five tracers. The concentrations for each of these solutes in various watershed sources and in stream water during base-flow and storm-flow conditions are presented in Figures 3 and 4. Median concentrations for $\mathrm{Na}$ and $\mathrm{Si}$ were lowest in surficial sources (precipitation, throughfall, stemflow, and litter leachate) and highest in groundwater sources (shallow, riparian and deep groundwaters) and thus these solutes represented tracers that characterized groundwater flow paths. In contrast, median values for $\mathrm{Al}$ and DOC were highest for surficial watershed sources such as throughfall, stemflow, and litter leachate and thus represented tracers that reflected surficial flow paths. The concentrations for $\mathrm{Ca}$ revealed a mixed pattern with highest median values for litter leachate followed by wetland soil water and groundwater sources (shallow and deep ground waters). Thus, compared to the other selected tracers, $\mathrm{Ca}$ was not as strong a tracer to differentiate between surficial and groundwater flow paths.

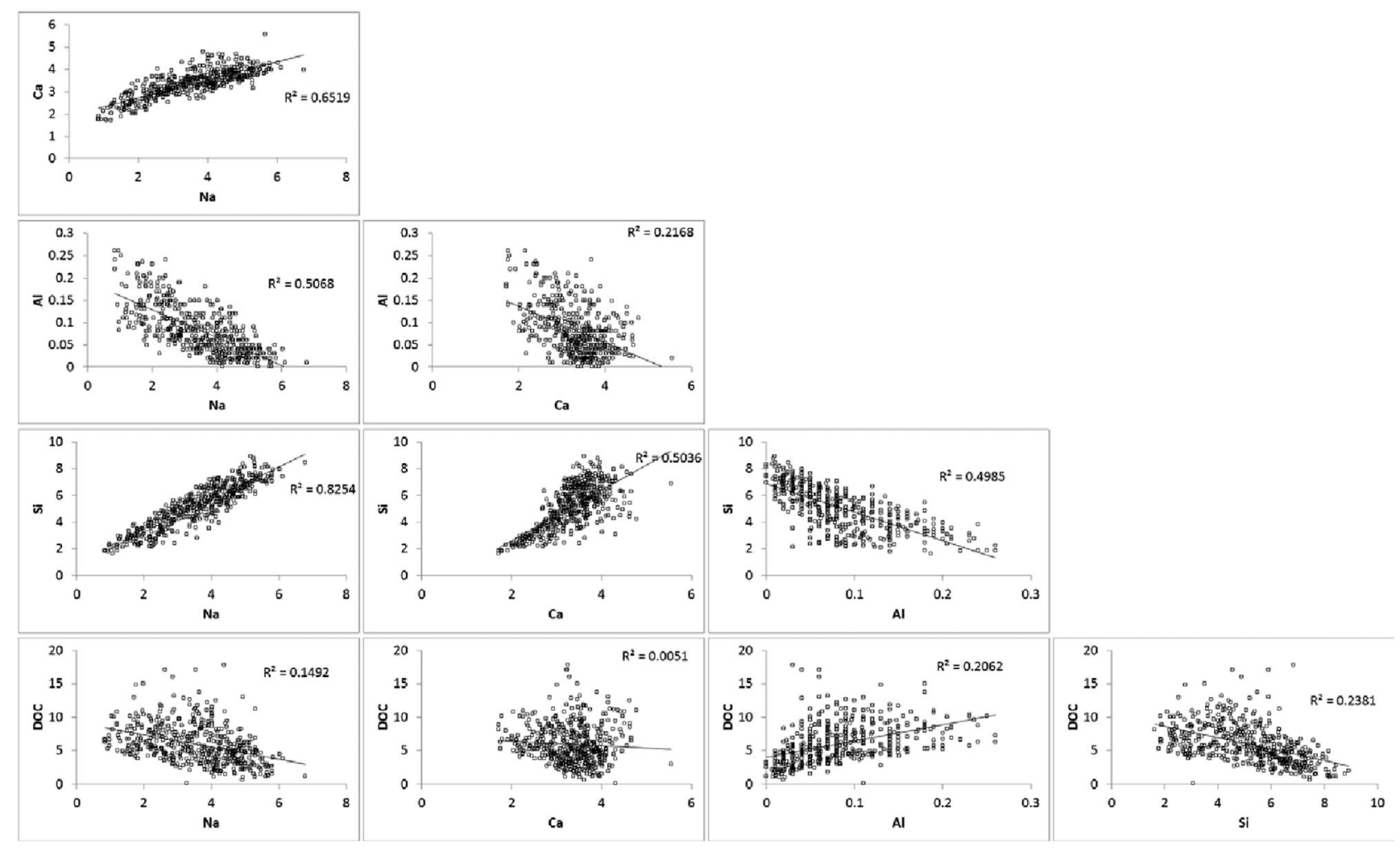

Figure 2. Bivariate plots of concentrations of the selected tracers for the sampled storm events. The selected tracers used in EMMA were: sodium $(\mathrm{Na})$, calcium $(\mathrm{Ca})$, aluminum (Al), silica ( $\mathrm{Si})$ and dissolved organic carbon (DOC). Regression coefficients $\left(\mathrm{R}^{2}\right)$ are included with each plot. 

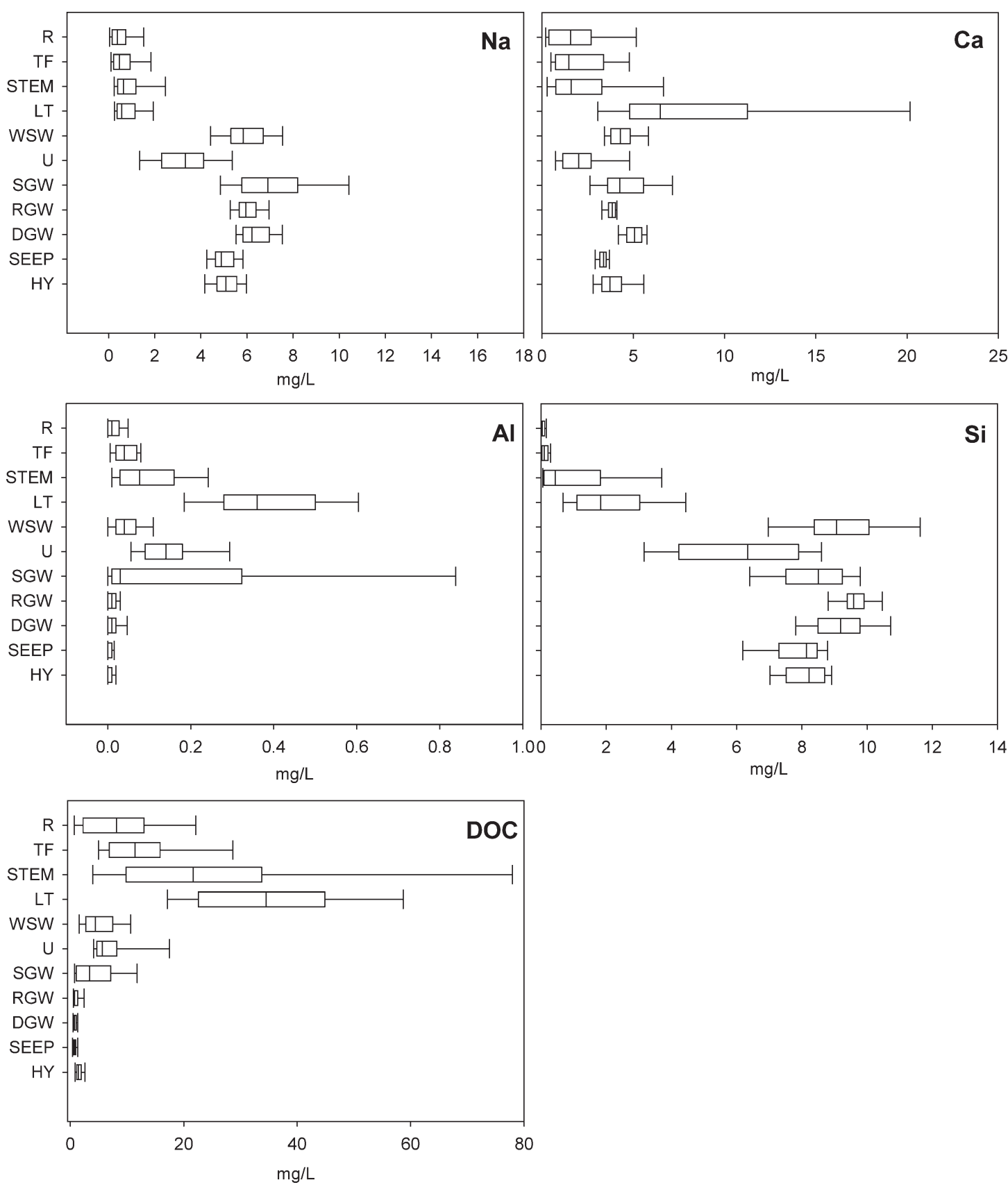

Figure 3. Concentrations $(\mathrm{mg} / \mathrm{L})$ of selected tracers in sampled watershed sources (runoff end-members). Tracers that were selected for EMMA were-sodium $(\mathrm{Na})$, calcium $(\mathrm{Ca})$, total aluminum $(\mathrm{Al})$, silica (Si), and dissolved organic carbon (DOC). The sampled end-members were- $\mathrm{R}$, precipitation; TF, throughfall; stem, stemflow; LT, litter leachate, WSW, wetland soil water; U, tension soil water; SGW, shallow ground water; RGW, riparian groundwater; DGW, deep groundwater; seep, groundwater seeps; and HY, hyporheic water. The line within the box indicates the median, the bounds of the box indicate 25 th and 75 th percentile, and the error bars indicate the 10th and 90th percentile of the data set.

[17] Not surprisingly, the concentrations for $\mathrm{Na}$ and $\mathrm{Si}$ in stream water during base flow were greater than the corresponding storm-flow values (Figure 4). In contrast, DOC and $\mathrm{Al}$ values for stream water during storm flow were much higher than the base-flow values (Figure 4). Aluminum concentrations in stream water during base flow were very close to zero. However, Al was a good tracer for storms since $\mathrm{Al}$ concentrations increased dramatically dur- ing storms (compared to the low base-flow values) and displayed linear fits with DOC in bivariate mixing plots.

\subsection{Watershed Sources in EMMA Space}

[18] Median concentrations for watershed sources along with one standard deviation are projected in the EMMA mixing space that was defined by the storm-event values for stream water (Figure 5). The mixing diagram revealed a 

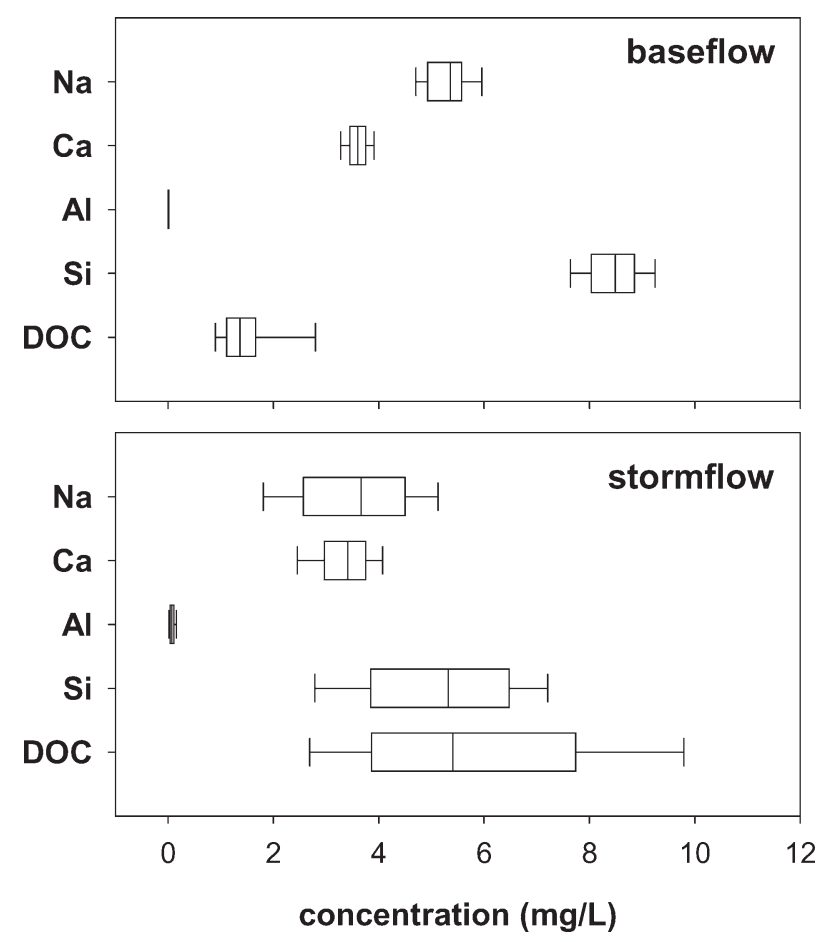

Figure 4. Concentrations $(\mathrm{mg} / \mathrm{L})$ of selected tracers in base flow and storm flow at the outlet of the 12 ha catchment (location ST3). The line within the box indicates the median, the bounds of the box indicate 25 th and 75 th percentile, and the error bars indicate the 10th and 90th percentile of the data set. systematic arrangement and orientation of watershed sources in EMMA space. The surficial watershed sources that included precipitation, throughfall, stemflow, and litter leachate were all aligned along a linear direction extending from quadrant 2 into quadrant 1 in the mixing space (Figure 5 ). The systematic sequencing of these end-members along this linear direction was intuitive as it represented water sources with similar (atmospheric) origin but with a progressive enrichment of solute/tracer concentrations from precipitation to litter leachate. In contrast, groundwater and soil water sources were located on the opposite end of the mixing space in quadrants 3 and 4. Seep groundwater, hyporheic water, and riparian groundwater were tightly clustered in quadrant 3 highlighting the similarity of water chemistry for these sources. On the other hand, wetland soil water and shallow groundwater sources were clustered together in quadrant 4 . The median value for deep groundwater occupied a region between the seeps and the soil water sources, but was shifted further to the left in the mixing space. Tension soil water, which represented the chemistry of water held in the soil pores, was located about midway between surficial sources and groundwater sources and was different from zero-tension wetland soil water.

[19] The variability of the surficial sources such as throughfall, stemflow, and litter leachate (indicated by one standard deviation error bars in Figure 5) was much greater than that for groundwater sources. Among all sources, variability was highest for litter leachate and lowest for riparian groundwater. To further investigate how chemistry of watershed sources varied over the year, we present seasonal values for selected watershed sources in EMMA space

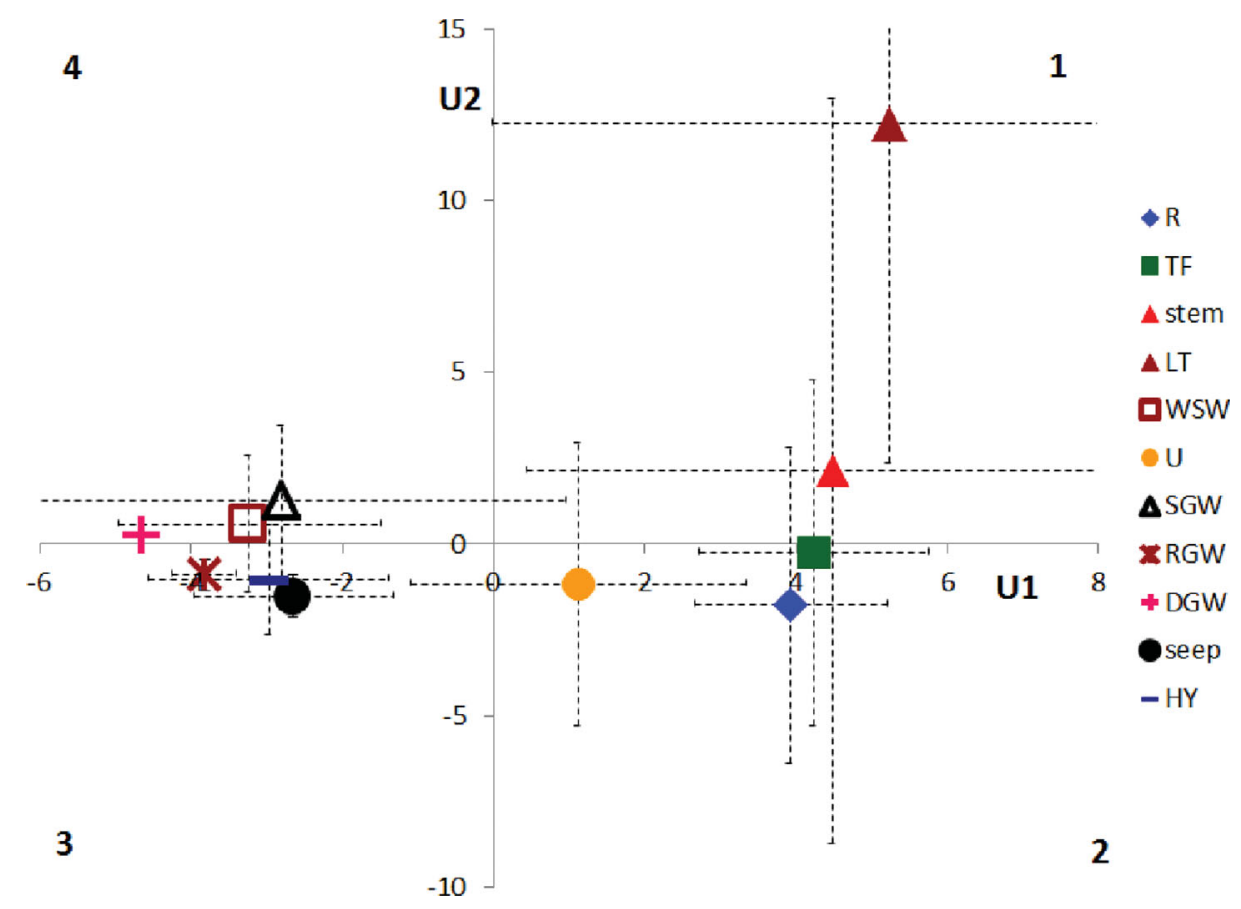

Figure 5. Concentrations of sampled end-members in two-dimensional EMMA mixing space. The EMMA space was defined by storm-event chemistry of stream waters and U1 and U2 indicate the first and second principal components. The sampled end-members are- $\mathrm{R}$, precipitation; TF, throughfall; stem, stemflow; LT, litter leachate, WSW, wetland soil water; U, tension soil water; SGW, shallow ground water; RGW, riparian groundwater; DGW, deep groundwater; seep, groundwater seeps; and HY, hyporheic water. 


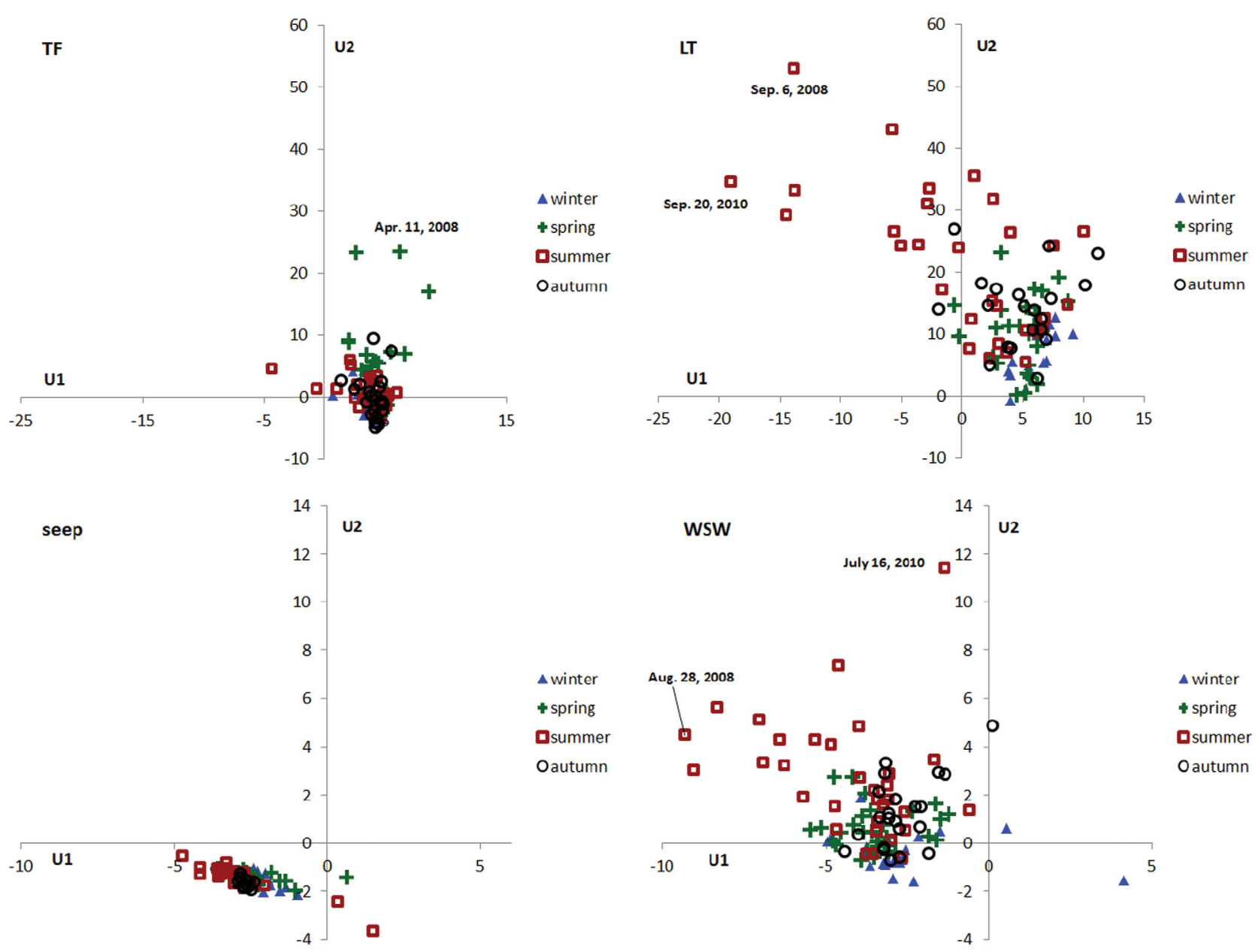

Figure 6. Seasonal variation in chemistry of selected end-members in two-dimensional EMMA mixing space. Seasons were defined as-winter, December through February; spring, March through May; summer, June through September; and autumn, October and November. The plotted end-members areTF, throughfall; LT, litter leachate; seep, groundwater seeps; and WSW, wetland soil water.

(Figure 6). Seasons were defined as — spring: March-May; summer: June-September; autumn: October-November; winter: December-February. Throughfall values associated with a few spring events were shifted upwards in quadrant 1 and further away from the remainder of the values in EMMA space. Similarly, litter leachate concentrations for summer (especially for the dry months of August-September) were shifted diagonally to the left into quadrant 4 and were considerably different from the litter leachate values observed for winter and spring. Wetland soil water also revealed a seasonal trend similar to litter leachate with dry summer conditions generating EMMA values that separated out from values for the remainder of the year. In contrast, seasonal differences in EMMA values for seeps were lower and these values were tightly clustered linearly in quadrant 3. Seasonal differences for other groundwater sources (e.g., riparian and deep groundwaters, not included here) were low and similar to that observed for seeps.

\subsection{Base Flow Versus Storm-Event Chemistry in EMMA Space}

[20] A total of 61 base-flow samples and 42 storm events (number of samples, $n=472$ ) were collected over the 3 year study period. Of the 42 storm events, 18 events $(n=207)$ were collected in 2008, 17 events $(n=193)$ in 2009, and seven events $(n=72)$ were sampled in 2010 . Of the 3 years, 2009 was the wettest with an annual precipitation amount of 1238 mm followed by 2008 with $1052 \mathrm{~mm}$ and 2010 with $972 \mathrm{~mm}$.

[21] All base-flow and storm-event data for the 3 years were plotted in the EMMA mixing space defined by the storm-event chemistry and are displayed in Figure 7. The first two principal components that were used to generate the 2-D mixing space in Figure 7 explained $68 \%$ and $20 \%$ of the variation in the storm-event data. When compared against the watershed sources in EMMA space, most of the base-flow values (open circles in Figure 7) were tightly clustered in the immediate vicinity of the groundwater seeps with a few values shifted toward the left (toward riparian groundwater) or right (surficial water sources). In comparison to the base-flow values, storm-event data (cross marks in Figure 7) displayed a strong shift toward surficial watershed sources (precipitation, throughfall, and litter leachate).

\subsection{Within-Event Evolution of Stream Water and the Influence of Watershed End-Members}

[22] To characterize the within-event evolution of stream water chemistry, five storms from 2008 to 2010 (27 July 2008; 31 July 2009 and 9 December 2009 and 13 December 


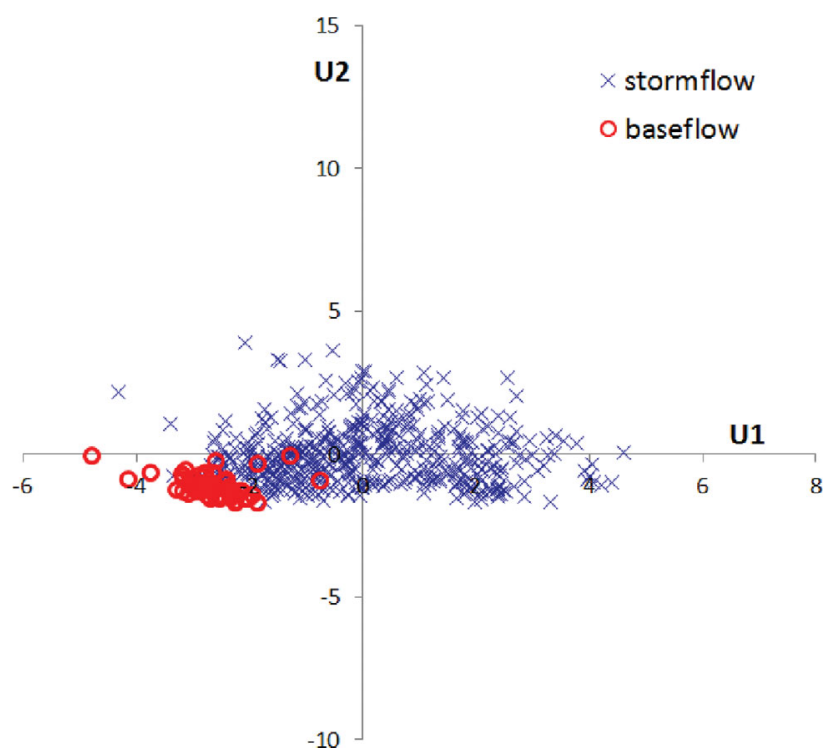

Figure 7. Chemistry of base flow (empty circles) and storm flow (hatch marks) in two-dimensional EMMA mixing space. The mixing space was defined by storm-event chemistry.

2009; 30 September 2010) are reported in Figure 8. Some of these events have also been reported previously in Inamdar et al. [2011] to characterize the flow paths for dissolved organic matter. Specific hydrologic attributes for the selected events are presented in Table 2 and the occurrence of these events over the 3 year period is displayed in Figure 9. The selected events represent a range in contrasting catchment wetness and hydrologic conditions and highlight important differences in hysteresis loops. Events in Table 2 were partitioned into three categories - wet, dry, and extremely dry representing three different levels of antecedent moisture conditions. These classifications were based on a combination of the antecedent metrics including AQ24hr and the 7 day groundwater depths for wells LW2, LW4, and LW5.

[23] In addition to stream water, the EMMA plots also contain values for all watershed sources that were associated with the selected events (except for stemflow which was not available for these selected events). End-member concentrations (other than precipitation, throughfall, and litter leachate which corresponded to the event itself) for the individual events were determined by taking the average of solute concentrations sampled immediately preceding and following the storm event. By including endmember concentrations in the immediate vicinity of the events or those associated with the events itself we can appropriately represent the temporal variation in end-member chemistry. Similar $X$ and $Y$ axes scales are maintained in the EMMA plots in Figure 8 so that the events can be directly compared against each other with a close-up view of the hysteresis loops. For events where the litter leachate end-member was at a considerable distance away from stream water (e.g., 27 July 2008 and 31 July 2009) only the end-member coordinates are reported.

[24] The EMMA plots for the five selected events highlight important similarities in within-event evolution of stream water chemistry (Figure 8). Hysteresis loops for all events followed a counter-clockwise rotation. In general, stream water started out in the vicinity of groundwater seeps followed by a pronounced shift in the direction of surficial sources (a region between throughfall and litter leachate) on the rising limb of the discharge hydrograph. This was followed by a shift toward shallow groundwater (SGW) and/or soil water (WSW) with an eventual return to groundwater sources on the recession limb of the discharge hydrograph.

[25] The selected events also highlighted important differences in within-event patterns for stream chemistry (Figure 8). The summer events (27 July 2008 and 31 July 2009) had more open and wider loops while the winter events (9 December 2009 and 13 December 2009) displayed tighter and more linear hysteresis patterns suggesting greater chemical uniformity of water sources during the latter period. Hydrologic data in Table 2 and Figure 9 show that the hydrologic conditions in the catchment for the summer and winter events were considerably different. The catchment was much drier (large groundwater depths for wells LW2, LW4, and LW5) during the summer versus the winter events. Prior to the event of 13 December 2009, the catchment was so wet that there was surface saturation and water ponding at well LW2 (negative depth values in Table 2). These wet conditions in winter resulted in greater streamflow discharges and higher runoff ratios for winter versus the summer events (Table 2). Another notable difference is the separation between groundwater (seep, riparian, and deep groundwaters) and soil water end-members (wetland soil water and shallow groundwater) (Figure 8). There appears to be a greater separation between the groundwater and soil water sources for the summer events whereas for the winter events the wetland soil water end-member is much closer to the groundwater end-members.

[26] The event of 30 September 2010 produced a complex and mixed response (Figure 8). This event was associated with remnants of Hurricane Nicole and was composed of two separate sub events (E1 and E2, precipitation total$=151 \mathrm{~mm}$, Table 2 and Figure 9) that amounted to $15 \%$ of the annual precipitation total for 2010. The precipitation amount for the September 30, 2010 event was equivalent to a 25 year, $24 \mathrm{~h}$ storm for this region (i.e., a return period of 25 years; Appendix C, see Ward and Trimble [2004]). The event occurred after an extended dry period during which one of the tributaries draining into ST3 had stopped flowing and the flow at ST3 itself was reduced dramatically. With the onset of the storm event, the specific stream discharge at ST3 increased 525 times from a pre-event value of 0.007 $\mathrm{mm} \mathrm{h}^{-1}$ to a peak event value (for E2) of $3.68 \mathrm{~mm} \mathrm{~h}^{-1}$. The event generated two hysteresis loops, both of which were counterclockwise, but with very different shapes and directional shifts in EMMA space. For ST3, the loop for E1 originated in the immediate vicinity of the seep and riparian groundwater sources and then shifted in the direction of litter leachate, followed by a shift toward soil water. Event E2 $(108 \mathrm{~mm})$ that had more than twice as much precipitation as E1 $(48 \mathrm{~mm})$ produced a very pronounced shift in stream water chemistry toward throughfall and precipitation end-members followed by an eventual return to groundwater sources.

[27] An evaluation of all event loops in Figure 8 suggests that at least three or four end-members are required to 

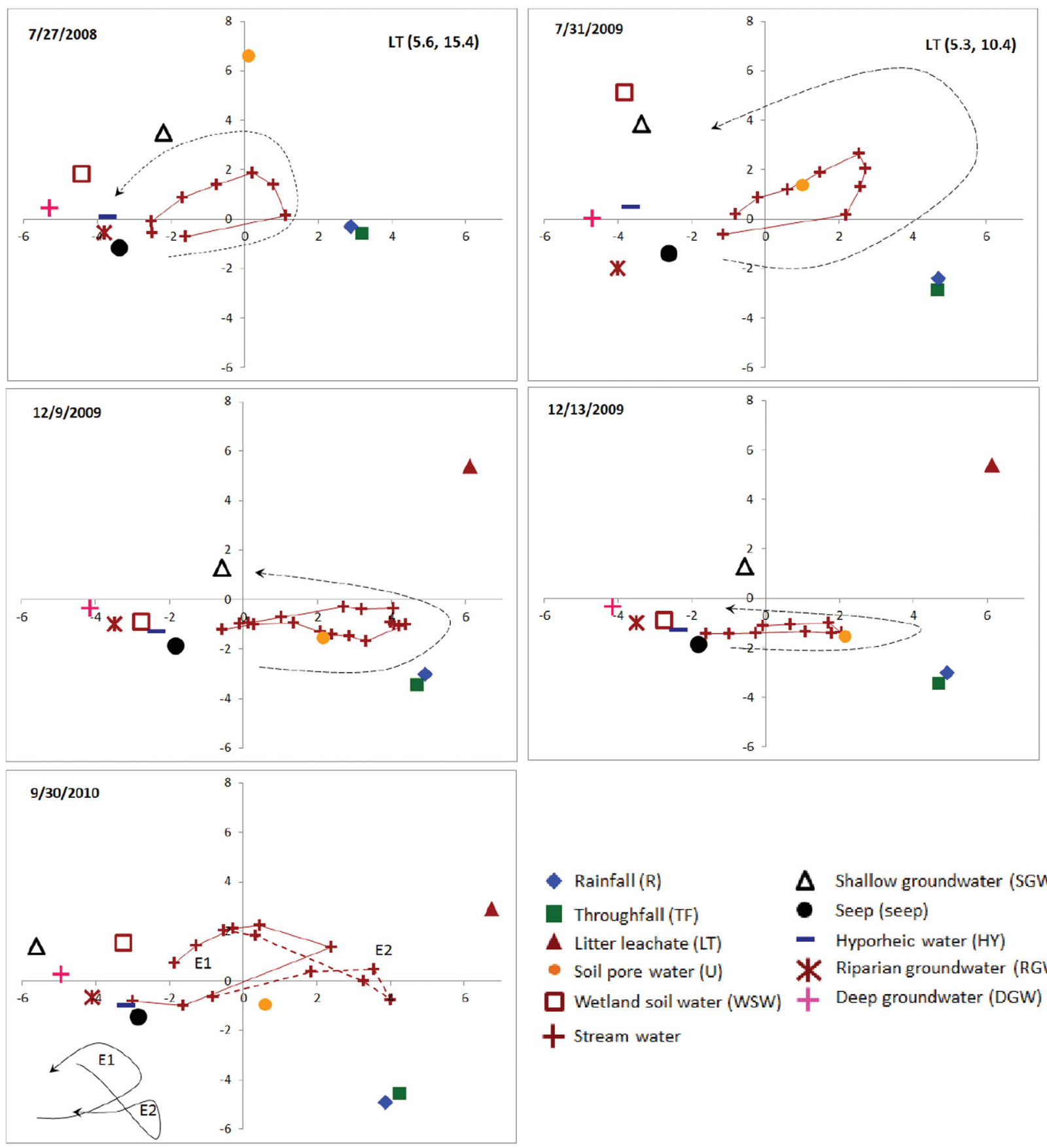
- Rainfall (R)
Throughfall (TF)
$\Delta$ Shallow groundwater (SGW)
A Litter leachate (LT)
- Seep (seep)
- Soil pore water (U)
- Hyporheic water (HY)
Wetland soil water (WSW)
K
Riparian groundwater (RGW)
+ Stream water

Figure 8. Within-event hysteresis loops for selected storm events in EMMA mixing space highlighting the shape and direction of the loops and the influence of end-members on stream water chemistry.

enclose the storm-event loops. While it is obvious that some of the end-members are located too close to each other in EMMA space to differentiate among them, it also appears that broad groupings of end-members can be made, especially, for the events that occurred under drier catchment conditions when the end-members tend to separate out. Overall, our analysis suggests that: (a) stream water was very similar to seep, riparian, or hyporheic groundwater sources at the start of the event; (b) throughfall and precipitation contributed to runoff on the rising limb of the hydrograph; (c) litter leachate contributions followed those from throughfall; and (d) soil or shallow groundwater sour- ces likely made up the early part of the streamflow recession limb before the eventual return to groundwater sources.

\subsection{Comparison of Storm-Event Mixing Patterns Over the Year}

[28] To investigate how runoff mixing patterns varied among storm-events occurring across different hydrologic and seasonal conditions we compared data for seven storm events each from 2008 to 2009 in EMMA mixing space (Figure 10). Importantly, in addition to determining the differences, the intent was also to investigate if the mixing 
Table 2. Temperature, Precipitation, Streamflow Discharge and Groundwater Depth Data for Selected Storm Events

\begin{tabular}{|c|c|c|c|c|c|c|c|c|c|c|c|}
\hline \multirow[b]{2}{*}{ Date (Month, Day, Year) } & \multirow[b]{2}{*}{$\mathrm{AT}^{\mathrm{a}}\left({ }^{\circ} \mathrm{C}\right)$} & \multicolumn{3}{|c|}{ Precipitation Data } & \multicolumn{4}{|c|}{ Streamflow Discharge } & \multicolumn{3}{|c|}{7 Day Groundwater Depths } \\
\hline & & $\begin{array}{l}\text { Amount } \\
(\mathrm{mm})\end{array}$ & $\begin{array}{c}5 \text { Min } \\
\text { Intensity }(\mathrm{mm})\end{array}$ & $\begin{array}{l}\text { API7 } \\
(\mathrm{mm})\end{array}$ & $\begin{array}{l}\text { Amount } \\
(\mathrm{mm})\end{array}$ & $\begin{array}{l}\text { Peak } \\
(\mathrm{mm})\end{array}$ & RR & $\begin{array}{l}\text { AQ24hr } \\
(\mathrm{mm})\end{array}$ & $\begin{array}{l}\text { LW2 } \\
(\mathrm{m})\end{array}$ & $\begin{array}{l}\text { LW4 } \\
(\mathrm{m})\end{array}$ & $\begin{array}{l}\text { LW5 } \\
\text { (m) }\end{array}$ \\
\hline \multicolumn{12}{|c|}{ Events during wet and/or cold catchment conditions } \\
\hline 1 Feb. 2008 & -1.8 & 36.1 & 1 & 7.2 & 7.71 & 1.19 & 0.21 & 0.029 & na & 1.047 & 0.661 \\
\hline 13 Feb. 2008 & 1.5 & 52.7 & 10.2 & 3.2 & 10.33 & 0.96 & 0.20 & 0.025 & na & 0.905 & 0.633 \\
\hline 11 Dec. 2008 & 4.7 & 59.1 & 2.9 & 13.2 & 15.81 & 3.33 & 0.27 & 0.072 & 0.284 & 1.1 & 0.66 \\
\hline 9 Dec. 2009 & 2.6 & 44.6 & 1 & 48.2 & 17.52 & 2.34 & 0.39 & 0.058 & 0.013 & 0.115 & 0.426 \\
\hline 13 Dec. 2009 & 0.1 & 25.2 & 0.9 & 50.7 & 8.88 & 0.876 & 0.35 & 0.0688 & -0.005 & 0.045 & 0.397 \\
\hline 26 Dec. 2009 & -4.5 & 49.1 & 0.7 & 13.7 & 25.5 & 1.05 & 0.52 & 0.07 & -0.022 & -0.0063 & 0.451 \\
\hline \multicolumn{12}{|c|}{ Events during dry catchment conditions } \\
\hline 20 Jul. 2008 & 23.8 & 33.4 & 10.3 & 12.1 & 1.99 & 0.27 & 0.15 & 0.009 & 0.209 & 0.414 & 0.855 \\
\hline 27 Jul. 2008 & 24.5 & 20.9 & 6.9 & 68.5 & 0.96 & 0.45 & 0.05 & 0.009 & 0.206 & 0.426 & 0.831 \\
\hline 26 Jul. 2009 & 20.1 & 14.8 & 6.1 & 22.4 & 0.68 & 0.35 & 0.05 & 0.0235 & 0.158 & 0.353 & na \\
\hline 31 Jul. 2009 & 21.8 & 30.9 & 11 & 37.4 & 1.85 & 0.88 & 0.06 & 0.0225 & 0.159 & 0.355 & na \\
\hline 2 Aug. 2009 & 22.1 & 27.8 & na & 63.9 & 2.68 & 2.02 & 0.10 & 0.022 & 0.156 & 0.347 & na \\
\hline 28 Oct. 2009 & 10.6 & 25.3 & 1.3 & 58 & 6.53 & 1.16 & 0.26 & 0.147 & 0.108 & 0.423 & 0.533 \\
\hline \multicolumn{12}{|c|}{ Events during very dry catchment conditions } \\
\hline 6 Sept. 2008 & 20.6 & 93.4 & 3.4 & 3.5 & 4.25 & 1.9 & 0.05 & 0.006 & 0.297 & 0.897 & 1.055 \\
\hline 25 Oct. 2008 & 6.8 & 13 & 3.8 & 13.7 & 0.6 & 0.37 & 0.05 & 0.06 & 0.324 & 1.1 & 0.797 \\
\hline 30 Sept. 2010 & 20.1 & $151(43,108)$ & 5.2 & 20 & 13.1 & 3.68 & 0.08 & 0.007 & 0.289 & 0.682 & 0.773 \\
\hline
\end{tabular}

${ }^{\mathrm{a}} \mathrm{AT} 7,7$ day average of air temperatures; API7, 7 day antecedent precipitation preceding the event; RR, runoff ratio, ratio of discharge amount and total precipitation for event; AQ24hr, average discharge for $24 \mathrm{~h}$ prior to event; 7 day groundwater depth, average of groundwater depth for 7 days preceding the event; na, data not available; negative values for groundwater depth indicate surface water ponding.
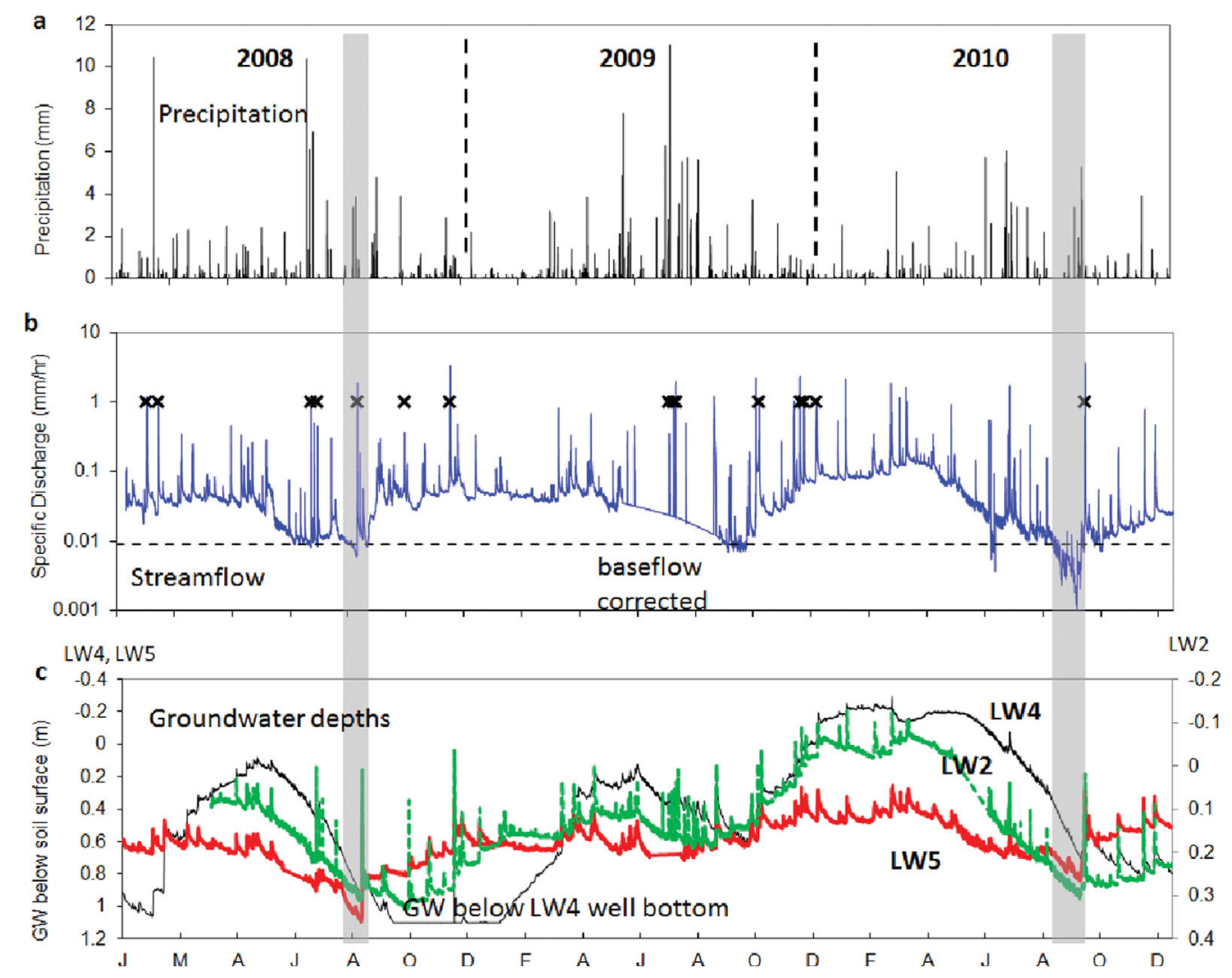

Figure 9. Time-series plot for the 3 years (2008-2010) for, (a) precipitation; (b) streamflow discharge at the catchment outlet (ST3) and the selected events (indicated by x) plotted in Figures 8 and 11; (c) groundwater depths for three wells, LW2, LW4, and LW5. The dashed line in Figure 9(b) indicates the approximate discharge $(0.009 \mathrm{~mm} / \mathrm{h})$ at which portions of the stream network dried up and were hydrologically disconnected. Shaded areas indicate time periods for which the stream drainage network was hydrologically disconnected. 


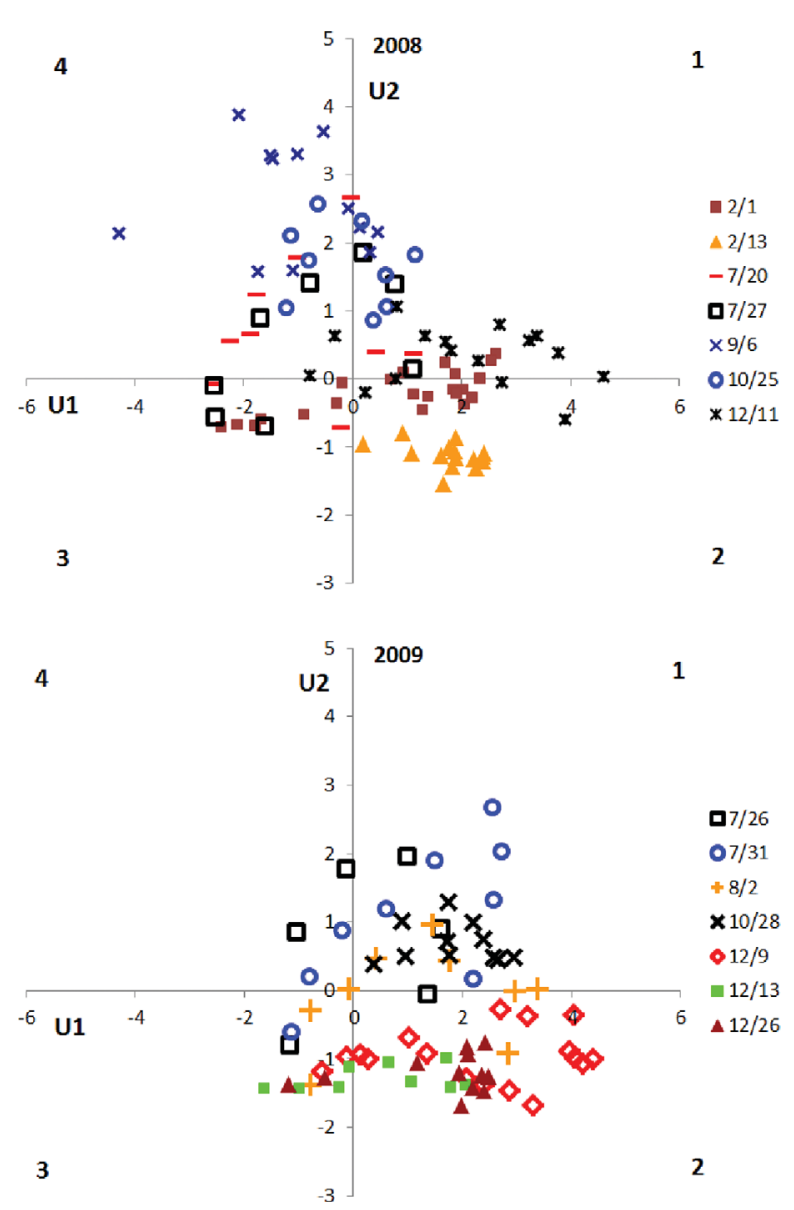

Figure 10. Selected events from 2008 to 2009 in EMMA mixing space highlighting the differences in mixing patterns among the storm events.

patterns were repeated for events occurring under similar hydrologic and seasonal conditions. Hydrologic attributes for the selected events are reported in Table 2 while their occurrences during the year are reported in the time-series plots in Figure 9.

[29] The summer events of 20 July 2008, 27 July 2008, 6 September 2008, 26 July 2009, 31 July 2009, and 2 August 2009 (Figure 10) were associated with convective storms that produced short duration, high-intensity precipitation and occurred when the catchment was subjected to hot and dry conditions (note air temperature and groundwater depths in Table 2 and Figure 9). In contrast, winter events such as 1 February 2008, 13 February 2008, 11 December 2008, 9 December 2009, 13 December 2009, and 26 December 2009 were associated with frontal systems that typically generated long-duration, low-intensity, and large precipitation amounts and occurred when the catchment conditions were wet and cold (soil frozen in February; note 7 day average air temperature in Table 2).

[30] The mixing diagrams reveal contrasting mixing patterns for summer and winter events. The high-intensity, summer storm events (e.g., 20 July 2008 and 27 July 2008; 26 July 2009, 31 August 2009, and 2 August 2009) had wide loops (as alluded to previously) which were shifted toward the upper part of the mixing space. In contrast, the winter events (e.g., 1 February 2008 and 13 February
2008; 9 December 2009, 13 December 2009, and 26 December 2009) displayed tight linear loops which preferentially occupied the lower portion of the EMMA mixing space. The location of the winter events in EMMA space suggests a greater expression of precipitation and/or throughfall for these events. It should be noted that by the latter half of November the deciduous forest canopy is without leaf cover, thus "throughfall" chemistry sampled at this time is more similar to precipitation chemistry than during leafed periods. Runoff events from spring (not included here) for which the moisture and temperature conditions were intermediate, occupied the EMMA region between the two extremes bounded by the summer and winter events.

[31] The late summer event of 6 September 2008 and the autumn events 25 October 2008 and 28 October 2009 produced complex mixing patterns that were different from the summer and winter events (Figure 10). Compared to other events, all three of these events were furthest away from the groundwater sources when the events occurred (Figures 5 and 10). Similar to the event of 30 September 2010, the event of 6 September 2008 occurred during one of the driest catchment conditions for the 3 year study period. Prior to these events the stream tributary at ST6 (Figure 1) had dried up and ceased flowing (similar to conditions prior to 30 September 2010) and the catchment drainage network was disconnected and fragmented. The mixing loop for 6 September 2008 was furthest away from other events in EMMA space and did not reveal a clear counter-clockwise rotation. While the AQ24hr value (Table 2) for the event of 25 October 2008 was nearly ten times that for the September events, the 7 day groundwater depth values were comparable, indicating that catchment soil conditions were still fairly dry preceding this event (also supported by our visual observations in the catchment). Contrary to all events, the event of 25 October 2008 yielded a clockwise hysteresis loop and did not display a strong shift toward any specific end-member. In comparison, the event of 28 October 2009 which occurred under wetter conditions (note AQ24hr and groundwater depths in Table 2), yielded a counter-clockwise loop with a shift in stream chemistry toward throughfall, followed by a return toward the seep end-member.

\section{Discussion}

\subsection{Watershed Sources in EMMA Mixing Space}

[32] Extensive data on 11 distinct watershed sources provided important insights both in terms of temporal variation in end-member chemistry as well as how these sources influenced base-flow and storm runoff chemistry. Watershed runoff sources enclosed stream water from all sides indicating that we had sampled/accounted for most of the sources contributing to runoff. The arrangement of runoff sources in two-dimensional EMMA mixing space was also fairly intuitive. For example, watershed sources such as precipitation, throughfall, stemflow, and litter leachate were all aligned sequentially along a linear direction extending from quadrant 2 to 1 (Figure 5); indicating that precipitation is progressively enriched in solutes as it travels through various parts of the forest canopy to the forest floor. While many previous studies have indeed reported precipitation and throughfall in EMMA mixing space [Inamdar and 

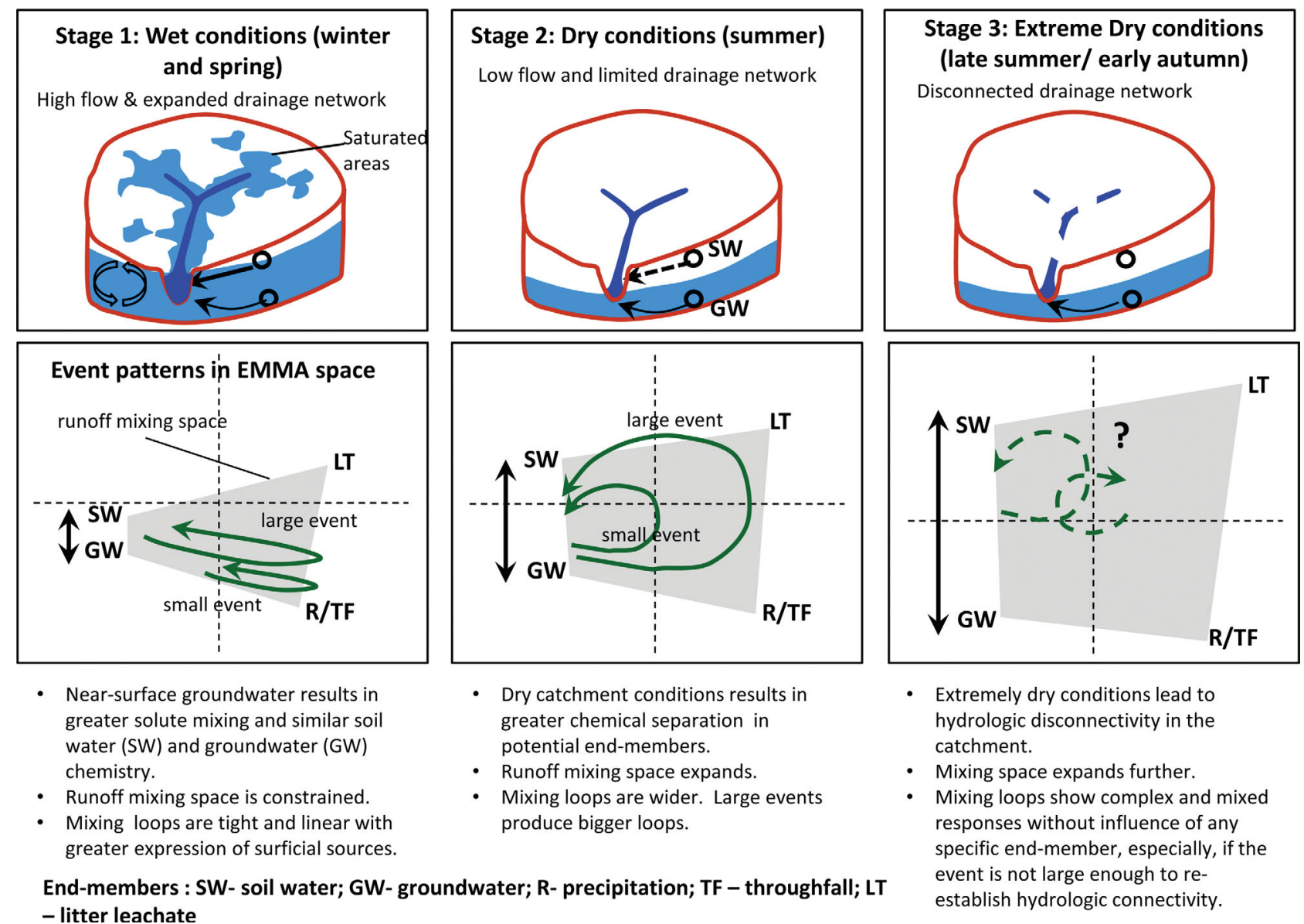

- Near-surface groundwater results in greater solute mixing and similar soil water (SW) and groundwater (GW) chemistry.

- Runoff mixing space is constrained.

- Mixing loops are tight and linear with greater expression of surficial sources.

End-members : SW- soil water; GW- groundwater; R-precipitation; TF - throughfall; LT - litter leachate establish hydrologic connectivity.

Figure 11. Conceptual model illustrating how the end-member chemistry, extent of mixing space, and storm-event hysteresis loops evolve as the catchment transitions from a wet, hydrologically wellconnected system (winter/spring, Stage 1) to a very dry, hydrologically disconnected state (late summer/ early autumn, Stage 3).

Mitchell, 2007; James and Roulet, 2006; Verseveld et al., 2008] this study has included all three important canopy sources i.e., throughfall, stemflow and litter leachate together to investigate their relative influence for stream water chemistry in EMMA space.

[33] While the temporal variation of end-member chemistry and its potential implications for runoff mixing have been recognized [Rice and Hornberger, 1998; Rademacher et al., 2005] specific information on how and when these changes occur for individual end-members has been lacking. Our results clearly show that temporal variation in endmember chemistry can be substantial, especially for surficial watershed sources such as litter leachate (LT) and soil water (WSW). Concentrations for these sources changed dramatically and were shifted upwards in EMMA space (further away from groundwater sources) during summer and especially for dry periods (Figure 5). We attribute these changes to the flushing of solutes that had accumulated in the surficial watershed sources and/or breakdown of substrates over the dry periods between storms. We speculate that these temporal changes in end-member chemistry played an important role in shaping the hysteresis loop patterns (wide versus tight linear loops) for summer and winter storm events (discussed in detail in a following section). In contrast to the surficial watershed sources, the temporal varia- tion in chemistry of groundwater sources was low. Not surprisingly then, this resulted in very little seasonal or temporal variation for base-flow chemistry in EMMA space (plots not included). These differences suggest that some end-members may require greater attention than others with respect to temporal variation for a runoff mixing model.

\subsection{Within-Event Runoff Mixing and a Model for Runoff Generation}

[34] Results from this study revealed a consistent withinevent pattern of end-member contributions to stream runoff. Except for events that occurred under extremely dry conditions (e.g., 6 September 2008 and 30 September 2010), the hysteresis loop for storm-event runoff followed a consistent counter-clockwise rotation with surficial source contributions on the rising limb and soil water contributions on the falling limb of the hydrograph. Previous studies have also reported similar patterns of end-member contributions with early expression of precipitation/throughfall followed by delayed expression of near-stream soil water or riparian water [Inamdar and Mitchell, 2007; Rice and Hornberger, 1998; Wenninger et al., 2004]. Working in a glaciated, forested watershed in Western New York, Inamdar and Mitchell [2007] reported that stream water was sustained by groundwater seeps during base flow, throughfall contributions 
occurred on the rising limb of the hydrograph and riparian water composed the hydrograph recession. Similarly, Rice and Hornberger [1998] found that storm event runoff was made up of throughfall, soil water and groundwater with contributions occurring in that order during the event. Observations by Pionke et al. [1988] in the Mahantango creek watershed in Pennsylvania (about $150 \mathrm{~km}$ northwest of our Maryland site) indicated that event water (precipitation and/ or throughfall) composed the rising limb of the discharge hydrograph whereas subsurface water from riparian saturated areas contributed later in the event. They attributed the early event water (precipitation or throughfall) to saturation-excess runoff generated off riparian saturated areas and the delayed expression of riparian water to displacement by the hillslope subsurface flux. Research in the Black Forest Mountains of Germany [Wenninger et al., 2004] has also shown that while event water may be expressed earlier as saturation overland flow, shallow groundwater from near-stream alluvial aquifers may be displaced by hillslope flux into the stream later in the event.

[35] We propose a similar conceptual model for hydrologic response for this study site where base flow is sustained by groundwater seeps and deep groundwater contributions; the rising limb of the hydrograph is composed of surficial runoff sources including precipitation, throughfall, and litter leachate that contribute via saturation overland flow off near-stream saturated areas; and soil water and/or shallow groundwater contributions occur later in the event likely due to displacement by infiltrating events waters and upslope hillslope flux. A few samples of saturation overland flow were collected during storm events for our study catchment and the chemistry was fairly similar to throughfall (data not included). The relative contributions from these end-members to stream runoff are regulated by catchment antecedent moisture conditions and precipitation amount and intensity as highlighted in the following paragraphs.

\subsection{Differences in Runoff Mixing Among Events and Conceptual Model}

[36] This study highlighted important differences in runoff mixing patterns and source contributions for storms that occurred during different times of the year and under contrasting hydrologic conditions. Three major patterns emerged from our observations: (a) storm events during winter and wet catchment conditions produced tight linear loops with a strong expression of surficial sources (precipitation and throughfall) in runoff; (b) storm events in summer and/or during dry catchment conditions generated wide, open loops which were shifted upwards in EMMA space; and (c) storm events that occurred during the driest catchment conditions (e.g., when stream tributaries had dried out in September 2008 and 2010) produced complex and/or mixed hysteresis loops without a pronounced influence of any specific end-members. Similar results have also been reported in previous studies. Rice and Hornberger [1998] observed "good" or well-defined mixing loops for events with the largest peak discharges or events with the wettest antecedent moisture conditions whereas "poor" mixing diagrams were associated with dry antecedent conditions. They speculated that the dry catchment conditions and moderate size of the events likely resulted in poor mixing of runoff components. Ali et al. [2010] found that wet catchment conditions produced the most hydrologically connected mixing model with contributions from all major runoff sources while drier catchment conditions mobilized fewer runoff components. Similarly, work by Bernal et al. [2006] in a Mediterranean catchment with strong dry-wet seasonal contrast indicated that storms immediately following the dry period (transition period) did not yield welldefined mixing patterns and end-members. They hypothesized that it was likely because of breakdown and/or buildup of solutes in the catchment over the dry periods which were then flushed out during the storm events. Bernal et al. [2006] alluded to the work of Butturini et al. [2005] who had suggested that under extreme drought conditions solutes in hyporheic and/or riparian sediments alone could provide a better explanation for the storm-event runoff chemistry as opposed to a conventional, complete, catchment-scale mixing model.

[37] We speculate that the three distinct runoff mixing patterns that we observed in our study were influenced by-(a) the temporal variation in end-member chemistry and (b) the antecedent moisture conditions and magnitude and intensity of the storm events that regulated hydrologic connectivity [Ali and Roy, 2009]. A three-stage conceptual model charactering these mixing regimes as a function of the catchment hydrologic conditions is presented in Figure 11. The catchment was generally at its wettest during winter and early spring (December-April). During these wet conditions, (Stage 1 in Figure 11) groundwater depths were closest to the soil surface and there was considerable mixing and exchange of solutes between the soil and groundwater end-members. This enhanced mixing and interaction was likely responsible for the chemical similarity between soil and groundwater end-members and their proximity in EMMA space (e.g., note end-members for events of 9 December 2009 and 13 December 2009 in Figure 8). This similarity and proximity of soil and ground water endmembers in EMMA space constrained the mixing space (shaded area in Figure 11) and produced hysteresis loops that were tight and linear in shape. The lengths of the loops were dictated by the amount of precipitation; greater precipitation amounts produced longer loops and a greater shift in the direction of precipitation/throughfall end-members. The strong expression of surficial watershed sources (e.g., precipitation, throughfall, stemflow, and litter leachate) during wet catchment conditions was not surprising considering that our visual observations during storm events revealed generation of substantial amounts of saturation-excess runoff in the catchment.

[38] As the catchment dried out over the summer (Stage 2 in Figure 11 and hydrologic attributes in Table 2), groundwater depths gradually increased and this resulted in a hydrologic decoupling of near-surface soil and the deeper groundwater end-members. The decoupling and hydrologic disconnectivity of the surficial (litter leachate and soil water) and groundwater end-members likely resulted in differences in chemical evolution and therefore a greater chemical separation of these end-members in EMMA space (e.g., note the seasonal shifts in end-members in Figure 6 and the differences in end-member chemistry for individual events in Figure 8). We believe this chemical separation of end-members and the consequent expansion of the EMMA 
mixing space was responsible for the wider event loops that were observed for the summer events. Again, larger and more intense storm events produced larger shifts toward surficial end-members and therefore larger hysteresis loops for the events.

[39] As the catchment further dried out through late summer and into early autumn (September - October; Stage 3 in Figure 11), especially for the years 2008 and 2010 (highlighted by shaded periods in Figure 9), an even higher level of hydrologic disconnectivity was established with the stream tributaries drying out. The catchment likely crossed a "hydrologic threshold" [Zehe and Sivapalan, 2009] at this point. From our visual observations of dried and disconnected streams and the measured discharge at ST3, we estimate that this hydrologic threshold for our catchment corresponded to a stream discharge value of approximately $0.009 \mathrm{~mm} \mathrm{~h}^{-1}$ (indicated by the dashed horizontal line in Figure 9b). Our visual observations in the catchment during these dry periods indicated that portions of the drainage network were fragmented into isolated pools of water and the stream bed for intermediate stream reaches was exposed and dry. Furthermore, while autumn leaf fall in our catchment typically occurs around the latter half of October, our visual observations indicate that drought conditions can occasionally initiate leaf fall as early as late September. Thus, in addition to the dry, hydrophobic soil surface, the forest floor and stream bed had a cover of dry leaves during this period.

[40] We suggest that the combination of hydrologic disconnectivity, dry hydrophobic soil surfaces, and the layer of dried leaves on the soil surface may have shaped the irregular mixing patterns for the events of 6 September 2008, 25 October 2008, and 30 September 2010. Both the events of 2008 produced runoff mixing loops that were furthest away from the groundwater end-members, and, while the event of September 6 displayed a mixed counter-clockwise rotation, the event of 25 October 2008 produced an unusual clockwise rotation. Precipitation inputs for neither of these two events were likely sufficient to establish hydrologic connectivity (precipitation for 25 October was especially small) in the catchment and produce a pronounced expression of runoff end-members. It is possible then, that similar to observations by Butturini et al. [2005], the stream water chemistry associated with these events was an incomplete mixture of end-members in the immediate vicinity of the hydrologically fragmented stream. Such end-members could include "soil water" from the stream sediments, wetland soil water, and/or limited contributions from throughfall and litter leachate which are directly intercepted by the stream channel. It is also likely that solutes that had accumulated over the drought period [e.g., Borken and Matzner, 2008] in the stream sediments and its vicinity were flushed out during these events. Runoff generation in the catchment could have been further complicated by runoff movement over dry, hydrophobic soils [Doerr et al., 2000]. The additional layer of dry leaves on the forest floor during late summer and early autumn could have also created a "thatched roof" effect [Ward and Robinson, 1990] or biomat flow [Sidle et al., 2007] for runoff.

[41] This hypothesis for Stage 3 is further reinforced by the hydrologic response for the large storm event of 30 September 2010 (Figure 8) which followed dry catchment conditions. The first subevent (43 $\mathrm{mm}$ of precipitation) produced a muted and clustered mixing loop representative of hydrologic disconnectedness in the catchment. However, the second subsequent subevent with a large precipitation input $(108 \mathrm{~mm})$ likely restored hydrologic connectivity and yielded a pronounced expression of precipitation and throughfall end-members in stream runoff (Figure 8).

\subsection{Implications for Catchment Hydrology and Biogeochemistry}

[42] Empirical observations from this study provided key insights into catchment behavior that have important implications for: (a) the use of geochemical mixing models or EMMA to characterize runoff sources; (b) streamflow hysteresis patterns as indicators of runoff sources; and (c) characterization of hydrologic connectivity via moisture metrics and hydrologic thresholds.

[43] Evaluation of 11 different runoff sources in EMMA space revealed that some of the sources were clustered tightly and that the sources were arranged systematically around the stream chemistry. This should not be unexpected since we do expect that the stream water is an integrated signal of catchment sources, especially, in hydrologically well-connected conditions. However, this does suggest that we need to be extremely cautious if we select three of four individual end-members to determine fractional or \% contributions to stream runoff. Furthermore, our observations showed that end-member chemistry, especially the surficial sources, could vary substantially with seasons and hydrologic conditions. This clearly violates the key assumption of temporal invariance for EMMA. This indicates that if EMMA is used to compute and compare runoff source contributions for individual events over the year, end-member chemistry in the immediate vicinity of the events needs to be monitored and used in the analyses. Temporal changes and differences in end-member chemistry also influenced the shape and areal extent of the runoff mixing space with consequences for stream chemistry.

[44] Hysteresis patterns for runoff chemistry have been used in catchment studies to predict the contribution and sequencing of runoff sources [Evans and Davies, 1998]. Our EMMA analyses showed that the shapes of these hysteresis loops (open and wide versus tight and linear) varied with seasons and hydrologic conditions and that knowledge of seasonal variation in end-member chemistry was critical in explaining some of these patterns. This underscores the need for better characterization and consideration of seasonal variation in runoff sources. In comparison to the changes in shapes of the hysteresis loops, the rotational direction was generally consistent with an anticlockwise rotation for most storm events. This suggests that the catchment behavior was fairly consistent and predictable for a variety of storms with a systematic sequencing of runoff sources. Exceptions occurred when the catchment experienced extremely dry conditions. It appears that some hydrologic threshold(s) was crossed beyond which the runoff sources were disconnected and decoupled and the stream drainage network was no longer an integrated signature of all sources in the catchment. Observations for our catchment suggest that such a hydrologic disconnection could have occurred when stream discharge dropped below 0.009 $\mathrm{mm} \mathrm{h} \mathrm{h}^{-1}$. However, discharge values and groundwater 
depths for the event of 25 October 2008 (Table 2) also suggested that while streamflow discharge increased and recovered, parts of the catchment were still very dry and likely disconnected. Following Ali and Roy [2010] and Ali et al. [2010], two key deductions that can be made from these observations are: (a) a single catchment metric (e.g., antecedent streamflow discharge) alone may not be sufficient to characterize hydrologic (dis) connectivity in the catchment and (b) that hydrologic connectivity is likely a combination of multiple catchment states or regimes. Ali and Roy [2009, 2010] proposed that hydrologic connectivity was likely a continuum of hydrological states which could not be defined by a single threshold and that a variety of metrics may be required to characterize the multiple catchment preferential states. We further speculate that in addition to moisture conditions influencing hydrologic connectivity, seasonal events such autumn leaf fall may enhance the "thatched roof" effect in forested catchments and further influence runoff generation.

\section{Conclusions}

[45] A rich data set on 11 runoff end-members and stream water chemistry spanning a period of 3 years and a wide range of hydrologic conditions provided important insights into temporal patterns of end-member chemistry and runoff mixing. This study revealed distinct differences and similarities in EMMA mixing loops and the extent of mixing space for storm events across multiple seasons and hydrologic conditions. Events that occurred under similar hydrologic conditions or seasons produced similar mixing responses suggesting a consistent, repeatable, catchment behavior. In contrast, the shapes and extent of the mixing space changed dramatically as the catchment evolved from a wet, hydrologically well-connected condition to a dry, disconnected state. Detailed data on watershed sources allowed us to attribute these changes in runoff mixing patterns to changes in end-member chemistry and their relative contributions to runoff. Tight, linear hysteresis loops for runoff were attributed to similar end-member chemistry under wet, well-mixed hydrologic conditions in the catchment. In contrast, chemical separation in end-member chemistry increased as the end-members became hydrologically disconnected under a drying catchment regime resulting in wide hysteresis loops and mixed responses. These results underscore the need to collect high-frequency data on both stream water as well as potential end-members to better understand and characterize the full range of diverse hydrologic responses and flow paths that may be expected in catchments. This information will become especially important under future climate-change conditions [Bender et al., 2010; Karl et al., 2009] in which storm events will likely become more intense with longer and drier intervals. Such observations are also critical for developing more reliable and representative models for runoff generation. In the absence of data on temporal changes in end-member chemistry, it is possible that catchment runoff mixing patterns could be incorrectly interpreted.

[46] Acknowledgments. This study was funded through a grant from the National Science Foundation (NSF, Hydrologic Sciences Program, EAR-0809205). We would like to thank Captain Wayne Suydam and the other Fair Hill NRMA staff for providing access to the study site. We are grateful to the Delaware Water Resources Center (DWRC) which provided a graduate assistantship to Gurbir Dhillon. We also thank Ethan Frost and Rachael Vaicunas for assisting with analyses, sampling and installation of equipment in the watershed. We are extremely grateful to Douglas Burns, two anonymous reviewers, and the editors of WRR whose constructive comments and suggestions were very helpful in revising this manuscript.

\section{References}

Ali, G., and A. Roy (2009), Revisiting hydrologic sampling strategies for an accurate assessment of hydrologic connectivity in humid temperate systems, Geogr. Compass, 3(1), 350-374.

Ali, G. A., and A. G. Roy (2010), Shopping for hydrologically representative connectivity metrics in a humid temperate forested catchment, Water Resour. Res., 46, W12544, doi:10.1029/2010WR009442.

Ali, G., A. G. Roy, M. Turmel, and F. Courchesne (2010), Source to stream connectivity assessment through end-member mixing analysis, $J$. Hydrol., 392, 119-135.

Barthold, F. K., C. Tyralla, K. Schneider, K. B. Vacheé, H.-G. Frede, and L. Breuer (2011), How many tracers do we need for end member mixing analysis (EMMA)? A sensitivity analysis, Water Resour. Res., 47, W08519, doi:10.1029/2011WR010604.

Bazemore, D. E., K. Eshleman, and K. J. Hollenbeck (1994), The role of soil water in stormflow generation in a forested headwater catchment: synthesis of natural tracer and hydrometric evidence, J. Hydrol., 162, 47-75.

Bender, M. A., T. R. Knutson, R. E. Tuleya, J. J. Sirutis, G. A. Vecchi, S. T. Garner, and I. M. Held (2010), Modeled impact of anthropogenic warming of the frequency of intense Atlantic hurricanes, Science, 327, 454458 .

Bernal, S., A. Butturini, and F. Sabater (2006), Inferring nitrate sources through end member mixing analysis in an intermittent Mediterranean stream, Biogeochemistry, 81(3), 269-289.

Blackmer, G. C. (2005), Preliminary bedrock geologic map of a portion of the Wilmington 30-BY 60-minute quadrangle, Open-file Rep. OFBM-05-01.0, 4th Series, Pennsylvania Geol. Surv., Southeastern Pennsylvania. [Available at http://www.dcnr.state.pa.us/topogeo/openfile/secompmap.pdf, accessed 3 Jan. 2009.]

Bonell, M. (1998), Selected challenges in runoff generation research in forests from hillslope to headwater drainage basin scale, J. Am. Water Resour. Assoc., 34(4), 765-785.

Borken, W., and E. Matzner (2008), Reappraisal of drying and wetting effects on $\mathrm{C}$ and $\mathrm{N}$ mineralization and fluxes in soils, Global Change Biol., 14, 1-17.

Burns, D. A., J. J. McDonnell, R. P. Hooper, N. E. Peters, J. Freer, C. Kendall, and K. J. Beven (2001), Quantifying contributions to storm runoff through end-member mixing analysis and hydrologic measurements at the Panola Mountain Research Watershed (Georgia, USA), Hydrol. Process., 15, 1903-1924.

Buttle, J. M. (2005), Isotope hydrograph separation of runoff sources, in Encyclopedia of Hydrological Sciences, edited by M. G. Anderson, pp. 1763-1774, John Wiley, New York

Butturini, A., S. Bernal, and F. Sabater (2005), Modeling storm events to investigate the influence of the stream-catchment interface zone on stream biogeochemistry, Water Resour. Res., 41, W08418, doi:10.1029/ 2004WR003842.

Christopherson, N., and R. P. Hooper (1992), Multivariate analysis of stream water chemical data: the use of principal component analysis for the end-member mixing problem, Water Resour. Res., 28, 99-107.

Doerr, S. H., R. A. Shakesby, and R. P. D. Walsh (2000), Soil water repellency: its causes, characteristics and hydro-geomorphological significance, Earth Sci. Rev., 51(1-4), 33-65.

Dewalle, D. R., B. R. Swistock, and W. R. Sharpe (1988), Three component tracer model for stormflow on a small Appalachian forested catchment, J. Hydrol., 104, 301-310.

Durand, P., and J. L. J Torres (1996), Solute transfer in agricultural catchments: The interest and limits of mixing models, J. Hydrol., 181, $1-22$.

Evans, C., and T. D. Davies (1998), Causes of concentration/discharge hysteresis and its potential as a tool for analysis of episode hydrochemistry, Water Resour. Res., 34(1), 129-137.

Hangen, E., M. Lindenlaub, Ch. Leibundgut, and K. von Wilpert (2001), Investigating mechanisms of stormflow generation by natural tracers and hydrometric data: a small catchment study in the Black Forest, Germany, Hydrol. Process., 15, 183-199. 
Hooper, R. P. (2001), Applying the scientific method to small catchment studies: a review of the Panola Mountain experience, Hydrol. Process., 15(10), 2039-2050.

Hooper, R. P. (2003), Diagnostic tools for mixing models of stream water chemistry, Water Resour. Res., 39(3), 1055, doi:10.1029/2002WR001528.

Hooper, R. P., N. Christopherson, and J. Peters (1990), End-member mixing analysis (EMMA): an analytical framework for the interpretation of streamwater chemistry, J. Hydrol., 116, 321-345.

Inamdar, S. P. (2011), The use of geochemical mixing models to derive runoff sources and hydrologic flow paths in watershed studies (invited chapter), in Forest Hydrology and Biogeochemistry: Synthesis of Past Research and Future Directions, edited by D. Levia, D. Carlyle-Moses, and T. Tanaka, Ecological Studies 216, pp. 163-183, Springer, NY, doi:10.1007/978-941365-5_8.

Inamdar, $\bar{S}$. P., and M. J. Mitchell (2007), Contributions of riparian and hillslope waters to storm runoff across multiple catchments and storm events in a glaciated forested watershed, J. Hydrol., 341, 116-130.

Inamdar, S., S. Singh, S. Dutta, D. Levia, M. Mitchell, D. Scott, H. Bais, and P. McHale (2011), Fluorescence characteristics and sources of dissolved organic matter for stream water during storm events in a forested mid-Atlantic watershed, J. Geophys. Res. Biogeosci., 116, G03043, doi: 10.1029/2011JG001735.

Inamdar, S., N. Finger, S. Singh, M. Mitchell, D. Levia, H. Bais, D. Scott, and P. McHale (2012), Dissolved organic matter (DOM) concentrations and quality in a forested mid-Atlantic watershed, USA, Biogeochemistry, 108, 55-76, doi: 10.1007/s10533-011-9572-4.

James, A. L., and N. T. Roulet (2006), Investigating the applicability of end-member mixing analysis (EMMA) across scales: A study of small, nested catchments in a temperature forested watershed, Water Resour. Res., 42, W08434, doi:10.1029/2005WR004419.

Jung, H. Y., T. S. Hogue, L. K. Rademacher, and T. Meixner (2009), Impact of wildfire on source water contributions in Devil Creek, CA: Evidence from end-member mixing analysis, Hydrol. Process., 23, 183-200.

Karl, T. R., J. M. Mellilo, and T. C. Peterson (2009), Global Climate Change Impacts in the United States, Cambridge Univ. Press, New York, N. Y.

Levia, D. F., J. T. Van Stan II, S. M. Mage, and P. W. Kelley-Hauske (2010), Temporal variability of stemflow volume in a beech-yellow poplar forest in relation to tree species and size, J. Hydrol., 380, 112-120.

Maryland State Climatologist Office Data Page (2012), [Available at: http:// metosrv2.umd.edu/ climate/cono/norm.html, accessed Apr. 2012.]

McGlynn, B. L., and J. J. McDonnell (2003), Quantifying the relative contributions of riparian and hillslope zones to catchment runoff, Water Resour. Res., 39(11), 1310, doi:10.1029/2003WR002091.

McHale, M. R., J. J. McDonnell, M. J. Mitchell, and C. P. Cirmo (2002), A field-based study of soil water and groundwater nitrate release in an Adirondack forested watershed, Water Resour. Res., 38(4), 2-1:2-16, doi:10.1029/ 2000WR000102.

Morel, B., P. Durand, A. Jaffrezic, G. Grau, and J. Molenat (2009), Sources of dissolved organic carbon during stormflow in a headwater agricultural catchment, Hydrol. Process., 23, 2888-2901.
Pionke, H. B., J. R. Hoover, R. R. Schnabel, W. J. Gburek, J. B. Urban, and A. S. Rogowski (1988), Chemical-hydrologic interactions in the nearstream zone, Water Resour. Res., 24(7), 1101-1110.

Rademacher, L. K., J. F. Clark, D. W. Clow, and G. B. Hudson (2005), Old groundwater influence on stream hydrochemistry and catchment response times in a small Sierra Nevada catchment: Sagehen Creek, California, Water Resour. Res., 41, W02004, doi:10.1029/2003WR002805.

Rice, K. C., and G. M. Hornberger (1998), Comparison of hydrochemical tracers to estimate source contributions to peak flow in a small, forested headwater catchment, Water Resour. Res., 34, 1755-1766.

Robson, A., K. J. Beven, and C. Neal (1992), Towards identifying sources of subsurface flow: a comparison of components identified by a physically based runoff model and those determined by chemical mixing techniques, Hydrol. Process., 6, 199-214.

Sebestyen, S.D., E. Boyer, J.B. Shanley, C. Kendall, D.H. Doctor, G.R. Aiken, and N. Ohte (2008), Sources, transformations, and hydrological processes that control stream nitrate and dissolved organic matter concentrations during snowmelt in an upland forest. Water Resources Research, Vol 44, W12410, doi:10.1029/2008WR006983.

Shanley, J. B., C. Kendall, T.E. Smith, D.M. Wolock, J.J. McDonnell (2002), Controls on old and new water contributions to stream flow at some nested catchments in Vermont, USA. Hydrological Processes, 16: 589-609.

Shanley, J. B., W. H. McDowell, and R. F. Stallard (2011), Long-term patterns and short-term dynamics of stream solutes and suspended sediment in a rapidly weathering tropical watershed, Water Resour. Res., 47, W07515, doi:10.1029/2010WR009788.

Sidle, R. C., T. Hirano, T. Gomi et al (2007), Hortonian overland flow from Japanese forest plantations - an aberration, the real thing, or something in between? Hydrol Process $21: 3237-3247$.

Sklash, M.G., R.N. Farvolden, and P. Fritz (1976), A conceptual model of watershed response to rainfall developed through the use of oxygen-18 as a natural tracer. Canadian Journal of Earth Science 13: 271-283.

Soulsby, C., J. Petry, M. J. Brewer, S. M. Dunn, B. Ott, and I. A. Malcom (2003), Identifying and assessing uncertainty in hydrological pathways: A novel approach to end member mixing in a Scottish agricultural catchment, J. Hydrol., 274, 109-128.

USGS (2008), [Available at: http://md.water.usgs.gov/surfacewater/ streamflow/bigelk.html, accessed 1 Mar. 2009.]

Verseveld, W. J., J. J. McDonnell, and K. Lajtha (2008), A mechanistic assessment of nutrient flushing at the catchment scale, J. Hydrol., 358, 268-287.

Ward, A. D., and S. W. Trimble (2004), Environmental Hydrology, 2nd ed., CRC Press, New York.

Ward, R. C., and M. Robinson (1990), Principles of Hydrology, 450 pp., McGraw-Hill, Berkshire, U. K.

Wenninger, J., S. Uhlenbrook, N. Tilch, Ch. Leibundgut (2004), Experimental evidence of fast groundwater responses in a hillslope/floodplain area in the Black Forest Mountains, Germany, Hydrol. Process., 18, 3305-3322.

Zehe, E., and M. Sivapalan (2009), Threshold behavior in hydrological systems as (human) geo-ecosystems: manifestations, controls, implications, Hydrol. Earth Syst. Sci., 13, 1273-1297. 